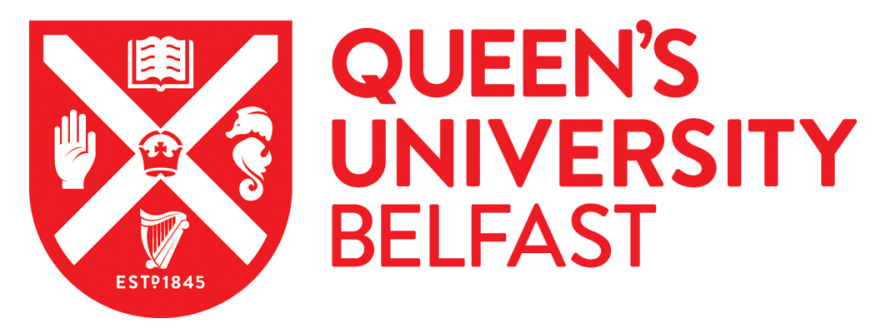

\title{
Analysis of groundwater-level response to rainfall and recharge estimates in fractured hard rock aquifers, NW Ireland
}

Cai, Z., \& Ofterdinger, U. (2016). Analysis of groundwater-level response to rainfall and recharge estimates in fractured hard rock aquifers, NW Ireland. Journal of Hydrology, 535, 71-84.

https://doi.org/10.1016/j.jhydrol.2016.01.066

Published in:

Journal of Hydrology

Document Version:

Peer reviewed version

Queen's University Belfast - Research Portal:

Link to publication record in Queen's University Belfast Research Portal

Publisher rights

(c) 2016 Elsevier Ltd. This manuscript version is made available under the CC-BY-NC-ND 4.0 license http://creativecommons.org/licenses/bync-nd/4.0/ which permits distribution and reproduction for non-commercial purposes, provided the author and source are cited.

\section{General rights}

Copyright for the publications made accessible via the Queen's University Belfast Research Portal is retained by the author(s) and / or other copyright owners and it is a condition of accessing these publications that users recognise and abide by the legal requirements associated with these rights.

Take down policy

The Research Portal is Queen's institutional repository that provides access to Queen's research output. Every effort has been made to ensure that content in the Research Portal does not infringe any person's rights, or applicable UK laws. If you discover content in the Research Portal that you believe breaches copyright or violates any law, please contact openaccess@qub.ac.uk. 


\section{Accepted Manuscript}

Analysis of groundwater-level response to rainfall and estimation of annual recharge in fractured hard rock aquifers, NW Ireland

Zuansi Cai, Ulrich Ofterdinger

PII:

S0022-1694(16)30006-3

DOI: http://dx.doi.org/10.1016/j.jhydrol.2016.01.066

Reference: HYDROL 21025

To appear in: Journal of Hydrology

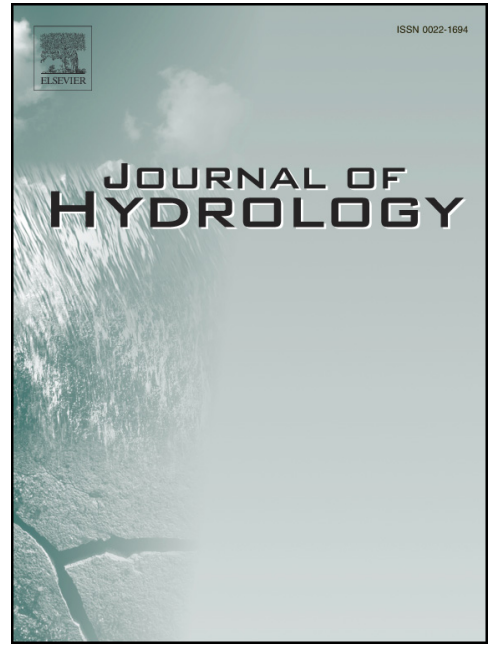

Received Date: $\quad 22$ July 2015

Revised Date: $\quad 20$ January 2016

Accepted Date: $\quad 24$ January 2016

Please cite this article as: Cai, Z., Ofterdinger, U., Analysis of groundwater-level response to rainfall and estimation of annual recharge in fractured hard rock aquifers, NW Ireland, Journal of Hydrology (2016), doi: http://dx.doi.org/ 10.1016/j.jhydrol.2016.01.066

This is a PDF file of an unedited manuscript that has been accepted for publication. As a service to our customers we are providing this early version of the manuscript. The manuscript will undergo copyediting, typesetting, and review of the resulting proof before it is published in its final form. Please note that during the production process errors may be discovered which could affect the content, and all legal disclaimers that apply to the journal pertain. 
1 Analysis of groundwater-level response to rainfall and estimation of annual recharge in fractured hard rock aquifers, NW Ireland

3

4

5

6

Zuansi $\mathrm{Cai}^{1}$ and Ulrich Ofterdinger

Groundwater Research Group, School of Planning Architecture and Civil Engineering, Queen's University Belfast, Belfast BT9 5AG, Northern Ireland, UK

\section{Abstract}

Despite fractured hard rock aquifers underlying over $65 \%$ of Ireland, knowledge of key processes controlling groundwater recharge in these bedrock systems is inadequately constrained. In this study, we examined 19 groundwater-level hydrographs from two Irish hillslope sites underlain by hard rock aquifers. Water-level time-series in clustered monitoring wells completed at the subsoil, soil/bedrock interface, shallow and deep bedrocks were continuously monitored hourly over two hydrological years. Correlation methods were applied to investigate groundwater-level response to rainfall, as well as its seasonal variations. The results reveal that the direct groundwater recharge to the shallow and deep bedrocks on hillslope is very limited. Water-level variations within these geological units are likely dominated by slow flow rock matrix storage. The rapid responses to rainfall ( $\leq 2$ hours) with little seasonal variations were obseryed to the monitoring wells installed at the subsoil and soil/bedrock interface, as well as those in the shallow or deep bedrocks at the base of the hillslope. This suggests that the direct recharge takes place within these units. An automated time-series procedure using the water-table fluctuation method was developed to estimate groundwater recharge from the water-level and rainfall data. Results show the annual recharge rates of 42-197 mm/yr in the subsoil and soil/bedrock interface, which represent 4-19\% of the annual rainfall. Statistical analysis of the relationship between the rainfall intensity and water-table rise reveal that the low rainfall intensity group $(\leqslant 1 \mathrm{~mm} / \mathrm{h})$ has greater impact on the groundwater recharge rate than other groups $(>1 \mathrm{~mm} / \mathrm{h})$.

This study shows that the combination of the time-series analysis and the water-table fluctuation method could be an useful approach to investigate groundwater recharge in fractured hard rock aquifers in Ireland.

\footnotetext{
${ }^{1}$ Corresponding author: Zuansi Cai, School of Planning Architecture and Civil Engineering, Queen's University Belfast, Stranmillis Road, Belfast BT9 5AG, Northern Ireland, UK (z.cai@qub.ac.uk)
} 


\section{Introduction}

28 Fractured plutonic and metamorphic rocks underlie over $65 \%$ of the island of Ireland. These hard rocks with generally low groundwater yield are often referred to as poorly productively bedrock aquifers (GSI, 2006; Robins and Misstear, 2000). Located in a temperate maritime climate where surface water resources are abundant, these hard rock aquifers have attracted little research interest to date in Ireland due to their limited role in public water supplies. As a result, knowledge of their role in sustaining surface water quality and ecosystem services is poorly constrained, partly due to a lack of detailed understanding of groundwater recharge processes, subsurface water movement within the fractured bedrock system and stream-aquifer interactions. With the implementation of the European Union Water Framework Directive (WFD), the Irish Environmental Protection Agency specifically instrumented a number of hard rock aquifer sites as part of its groundwater monitoring network (Moe et al., 2010). These instrumented sites were investigated as part of research activities funded under the Irish National Geoscience Programme. This resulted in recent research publications characterising hard rock groundwater systems using multi-scale hydrogeological and geophysical approaches (Cassidy et al., 2014; Comte et al., 2012), as well as hydrogeochemical and mineralogical investigations assessing groundwater contributions to river baseflows (Caulfield et al., 2014). Parallel studies funded under the EPA Strive Research Programme focussed on pollutant pathways across typical Irish catchment settings, including hard rock aquifer catchments (e.g. O'Brien et al., 2014). small number of studies make reference to hard rock aquifers in terms of recharge and the variability Despite some site studies of recharge estimates for the fractured limestone aquifer and sand \& gravel aquifer (e.g., Misstear et al., 2009b; Misstear et al., 2008), the main focus of research activities in the area of groundwater recharge over the last decade in Ireland was to develop a framework to assess groundwater vulnerability. This framework was to account for key factors, including permeability and thickness of superficial deposits, the presence of saturated soil and the hydrogeological properties of 
53

54

55

56

57

the underlying aquifer, to produce the national groundwater recharge map (Fitzsimons and Misstear, 2006; Misstear et al., 2009a; Swartz et al., 2003; Williams et al., 2013).

Recently, an investigation of a headwater catchment underlain by the hard rock aquifer in Gortinlieve, County Donegal, Ireland suggests that deep groundwater contributes to the maintenance of annual river baseflow levels (Caulfield et al., 2014). Other field investigations of igneous rock (granite) systems in Japan and US A have also reported that groundwater within the weathered bedrock zone beneath the subsoil on hillslopes contribute $14-95 \%$ to streamflow generation (cf. Salve et al., 2012). Studies in the UK and Australia reveal that there is significant groundwater flow through both shallow and deep fractured bedrocks which could provide much of stream input even during periods of high flow (Banks et al., 2009; Shand et al., 2007). Despite these studies providing different results with regard to the role of shallow and deep groundwater for streamflow generation which probably reflects specific differences in hydrogeological settings, all studies underline the importance of fractured hard rock systems in terms of transferring water and associated pollutants (e.g., nitrate) to surface water bodies (e.g., Paulwels et al., 2001; Pawar and Shaikh, 1995) . A better understanding of groundwater flow pathways within the Irish hard rock systems could help to implement a programme of measures to meet water quality targets required by the WFD.

To generate streamflow even at times of high flow, precipitation must transit the unsaturated zone of the hard rock system and cause a rapid groundwater-level response for delivering water to bordering streams. This is a function of groundwater recharge. To investigate how the hard rock system contributes to streamflow generation, we must understand the recharge processes within different geological units in the system. This requires monitoring installations within different geological zones of the hard rock system to investigate groundwater-level response to rainfall as well as to estimate recharge rates. There are a number of studies which have been reported using field instrumentation techniques (tensiometers and/or piezometers) to investigate groundwater processes on hillslopes underlain by the hard rock aquifers. Some focused on groundwater recharge (e.g., Kosugi et al., 2006; Salve et al., 2012), others focused on flow at the soil/bedrock interface (e.g., McDonnell, 1990; McGlynn et al., 2002) and aquifer-stream interactions (e.g., Banks et al., 2009; Tromp-van Meerveld 
et al., 2007; Uchida et al., 2003). With the newly established groundwater monitoring network in

different hard rock aquifer settings across Ireland, hydrogeological data (e.g., well log data,

groundwater levels and water quality) from different geological units have been collected from dozens

of high-quality clustered monitoring wells. These hydrogeological data (e.g., groundwater-level timeseries) in combination with the rainfall data provide new information to advance the understanding of key hydrological processes controlling groundwater flow and recharge in hard rock aquifers. These advancements can be achieved by joint analysis of rainfall and groundwater-level time-series.

87 Correlation and spectral analyses of rainfall and groundwater-level time-series has been used to identify recharge mechanisms in fractured aquifers (Chae et al., 2010; Jimenez-Martinez et al., 2013; Lee and Lee, 2000). The advantage of this approach is its simplicity and the widespread availability of groundwater-level data. The time-series analysis approach was introduced to investigate groundwater flow regimes and aquifer storage capacity in karst aquifers. (e.g., Larocque et al., 1998, Mangin, 1984; Padilla and Pulidobosch, 1995). The approach treats rainfall and spring discharge/piezometric level time-series as input and output signals, respectively. While the karst aquifer is considered as a filter which transforms, retains, or eliminates the input signal in the creation of an output signal. The groundwater-level/spring discharge response to rainfall is one of the key results of the analysis. Crosbie et al. (2005) later incorporated the time-series analysis approach into the water-table fluctuation (WTF) method for groundwater recharge estimate. In the improved WTF approach, the required time for groundwater-level response to rainfall (the time lag) was obtained from the correlation analysis of the water-level and rainfall data. The rise of water-table during the time lag is considered as a result of groundwater recharge. Groundwater recharge is estimated by the height of water-table build-up during/after a rainfall event times the specific yield (Healy and Cook, 2002). fluctuation methods to improve the understanding of groundwater recharge processes within the different geological layers in hard rock aquifers in northwest Ireland, as well as to estimate annual recharge rates. This is achieved by conducting correlation analyses of the groundwater-level timeseries, which are collected from clustered monitoring wells completed in the subsoil, at the 
107 soil/bedrock interface, and in the shallow and deep bedrocks at two hillslope sites underlain by

108 fractured hard rock in northwest Ireland. The analysis of the groundwater-level response to rainfall

109 from the clustered monitoring wells at high, intermediate and low slope elevations at each site

110 improves the conceptual understanding of groundwater recharge in the different geological layers of

111 the hard rock system. An automated time-series procedure using the water-table fluctuation method is

112 developed to estimate annual groundwater recharge rates within the geological layers, where the

113 direct recharge processes have been identified by correlation analyses.

\section{2. Site descriptions and well instrumentation}

115 Two hillslope hard rock sites in the west and northwest of Ireland were selected for this study (Figure

116 1a-c). The west site located in Co. Mayo, Glencastle (GC), is underlain by a suit of the high grade

117 metamorphic gneisses, schists and quartzites. The northwest site located in Co. Donegal, Gortinlieve

118 (GO), is underlain by the intermediate grade metamorphic rocks of Precambrian pisammitic

119 micaschists, with occasional marbles of the Dalradian Southern Highland Group. The hydrogeological

120 characterisation of both sites has been carried out using various tools including surface geophysics,

121 downhole geophysics, single well tracer tests, hydraulic testing and fracture mapping (Comte et al.,

122 2012; Deakin et al. 2015, Ofterdinger et al. 2015; Nitsche 2014). According to the conceptualisation

123 of poorly productive aquifers in Ireland (Comte et al., 2012; Moe et al., 2010), four depth-dependant

124 lithological zones are commonly defined: 1) Subsoil (SS)-overburden deposits such as glacial till and

125 alluvium; 2) Transition Zone (TZ)- the overburden/bedrock interface containing highly permeable

126 decomposed and broken bedrock; 3) Shallow Bedrock (SB)-slightly permeable fractured and

127 weathered upper bedrock; and 4) Deep Bedrock (DB)-massive un-weathered bedrock. Figures 1d-e

128 show the schematic cross-section of the hydrogeological units represented by the four hydraulically

129 distinctive zones for both sites.

130 Both sites have been instrumented with three well clusters along a hillslope profile by the Irish

131 Environmental Protection Agency in 2006 as part of a wider groundwater monitoring programme.

132 Each well cluster consists of up to four screened or open-hole monitoring wells which were completed

133 within one of the hydraulically distinct zones of the bedrock aquifer (Figure 1d-e). The three well 
134

135

136

137

138

139

140

141

142

143

144

145

146

147

148

149

150

151

152

153

154

155

156

157

158

clusters at each site constitute a linear transect at high (GC1 \& GO1: 64 \& $176 \mathrm{~m}$ amsl), intermediate (GC2 \& GO2: $30 \& 89 \mathrm{~m}$ amsl) and low (GC3 and GO3: $18 \& 34 \mathrm{~m}$ amsl) elevations. The depth of the monitoring well varies from 2 to 79 m below ground surface. The summary of the well specifications are detailed in Table A.1. The schematic cross-section of the monitoring wells installation in the hydrogeological units is presented in Figures 1d-e.

\section{Data acquisition}

All the monitoring wells were instrumented with data loggers, which have been consecutively logging groundwater levels on 15-minute intervals since late 2000s. During the period between October 2010 and September 2012, on a number of days no water-level records were available due to hydraulic tests being completed in some wells. A linear interpolation was used to fill these data gaps in this study. Rainfall measurements at the Gortinlieve site has been recorded by two automated tipping bucket rain gauges (AEG 100) since October 2010, with one gauge installed at the high ground elevation close to GO1 and another installed at the low ground elevation close to GO3. Rainfall was recorded in 15minute or one hour intervals. During the period between October 2010 and September 2012, there are some short time periods without rainfall measurements due to blockage in the upper and/or lower rain gauges. Missing rainfall measurements at each rainfall station were filled by measurements either from the rain gauge at the top or at the base of hillslope in this study, respectively. For the periods where no rainfall records were measured by the both rain gauges, these data gaps were filled by the rainfall records from the Ballykelly weather station (Lon: $-7^{\circ} 1^{\prime} ;$ Lat: $55^{\circ} 4^{\prime} ; \sim 25 \mathrm{~km}$ northwest of Gortinlieve, Figure 1a). As the Glencastle site is close to the Met Eireann synoptic station in Belmullet (Figure1a), rainfall measurements from the Belmullet synoptic station were used to represent the rainfall in the Glencastle site. A previous study suggests a strong correlation between the rainfall measurement on the site and the synoptic station (McGrath, 2008). Overall, the hourly rainfall and groundwater-level data over two hydrological years (October 2010 to September 2012) were used in this study. 
159

160

161

162

163

164

165

166

167

168

169

170

171

172

173

174

175

176

177

178

179

180

181

182

183

184

\section{Time-series analysis}

\subsection{Auto- and cross-correlations}

Autocorrelation is the cross-correlation of a time-series with itself at different points in time. This function quantifies the linear dependency of successive values over a time period (Larocque et al. 1998) and investigates the "memory effect" (the required time for a system to "forget" its initial conditions) (Mangin, 1984). For an uncorrelated time-series (e.g., rainfall), the autocorrelation function exhibits a sharp decline from one to below a predefined value (usually 0.2 ) within a short time lag. In contrast, an autocorrelation function that exhibits a slow decline for a long time lag suggests that the time-series has strong interdependency and a long memory effect. The mathematical expression of the auto-correlation function can be written as:

$$
\begin{gathered}
C(k)=\frac{1}{n} \sum_{t=1}^{n-k}\left(x_{t}-\bar{x}\right) \cdot\left(x_{t+k}-\bar{x}\right), k \geq 0 \\
\gamma(k)=\frac{C(k)}{C(0)}
\end{gathered}
$$

where $C(k)$ is the correlogram, $n$ is the length of the time-series, $k$ is the time lag ( $k=0$ to $m$, $m \leq n / 3), x_{t}$ is the value of studied variables at time $t, \bar{x}$ is the mean value of the series $x_{t}, \gamma(k)$ is the auto-correlation function.

The cross-correlation analysis considers transformation of the input to the output signals. The crosscorrelation function represents inter-relationship between the input and output time-series. For a random input series, the cross-correlation function corresponds to the impulse response. For the cases where the cross-correlation function is not symmetrical and has a maximum or minimum for a positive lag, this indicates that the input signal has some impacts on the output signal. The lag time which corresponds to the maximum of the cross-correlation function is defined as the response time. In this study, the response time obtained from the cross-correlation function between rainfall and groundwater-level time-series corresponds to the mean response time of the water-level in a well to rainfall events. This is similar to the concept which has been used to investigate discharge in the karst aquifers (e.g., Mangin, 1984). The mathematical expression of the cross-correlation function can be written as: 


$$
C_{x y}(k)=\frac{1}{n} \sum_{t=1}^{n-k}\left(x_{t}-\bar{x}\right) \cdot\left(y_{t+k}-\bar{y}\right)
$$

$$
\gamma_{x y}(k)=\frac{c_{x y}(k)}{\sigma_{x} \sigma_{y}}
$$

where $C_{x y}$ is the cross-correlogram, $k$ is the time lag; $n$ is the length of the time-series, $x_{t}$ and $y_{t}$ are

respectively, $\gamma_{x y}$ is the cross-correlation function, and $\sigma$ is the standard deviation of the time-series.

To exhibit a significant correlation between input and output time-series at the $95 \%$ confidence interval, the cross-correlation function must have a correlation coefficient greater than the standard error $\sim 2 / \mathrm{N}^{0.5}$, where $\mathrm{N}$ is the number of values in the time-series data (Diggle, 1990; Lee et al., 2006).

\subsection{Sliding window cross-correlation method}

194 The cross-correlation analysis generally considers multi-year time-series data to reveal the general inter-relationship between input and output time-series over the data period. Delbart et al. (2014) proposed a sliding window cross-correlation method for the analysis of temporal variability of groundwater-level response to rainfall in a karst aquifer. This new cross-correlation method separates the whole input and output time-series data into sets of three-month data windows. Each data window has a one-and-a-half-month data overlap with its previous and/or following data windows and then the cross-correlation analysis is conducted for each data window to reveal the seasonal variability of the impulse response.

\section{Water-table fluctuation method}

The water-table fluctuation (WTF) method is based on the assumption that rises of the water-table in unconfined aquifers are attributed to recharge water arriving at the water-table. In the WFT method, groundwater recharge is estimated by the height of water-table build-up during/after a rainfall event times the specific yield (Healy and Cook, 2002). The mathematical expression can be written as:

$$
R=S_{y} \frac{\Delta h}{\Delta t}
$$

where $R$ is groundwater recharge; $S_{y}$ is specific yield; and $\Delta h$ is change in water-table height over the 
immediately into storage. This means that the impact of the lateral groundwater flow on water-level

211 decline during a recharge event (drainage effect) is ignored, which could underestimate the actual

212 recharge rate. Crosbie et al (2005) improved the WTF method to account for the drainage effect using

213 the rainfall and groundwater-level time-series data. With accounting for the drainage effect, the

214 groundwater recharge estimate in Equation (5) is revised for time-series data:

$$
R_{t}=\left\{\begin{array}{c}
{\left[\left(h_{t}-h_{t-1}\right)+D \Delta t\right] S_{y} \text { if }\left\{\begin{array}{c}
{\left[\left(h_{t}-h_{t-1}\right)+D \Delta t\right]>0} \\
\text { and } \\
\sum_{t-t_{r}<t^{\prime}<t} P_{t^{\prime}}>0 \\
\text { otherwise }
\end{array}\right.}
\end{array}\right.
$$

where $R_{t}$ is recharge at time $\mathrm{t}, h_{t}$ is water-level at time t, $D$ is drainage rate (which accounts for how

far the water level would have fallen had recharge not occurred), $\hat{P}_{t}$ is the sum of rainfall during the groundwater-level response time ( $\mathrm{t}$ ', groundwater-level response time: the required time period to groundwater-level rise after a rainfall event which is determined by the cross-correlation analysis of the rainfall and groundwater-level time-series data).

The processes used in this study for the recharge estimate are summarised as: 1) determine the drainage rate as a function of the water-table height. Daily water-table decline rates at each well were determined by analysing the groundwater-level record of those days in the 2-year observation period, where no rainfall occurs during the day and its antecedent response time period. The drainage rate was determined by a linear fitting process of daily water-table decline to its corresponding water-table height; 2) add the drainage term into the hourly water-table change time-series with the antecedent rainfall $\left.\left(P_{t^{\prime}}>0\right) ; 3\right)$ conduct the cross-correlation analysis between the newly updated water-table change and rainfall time-series, and update the response time if it has been changed; this process is to account for the impact of the drainage effect on water-table change; 4) remove all negative terms in the water-table change time-series; 5) remove all positive terms with no antecedent rainfall $\left(P_{t^{\prime}}=0\right)$; this process is to eliminate/limit the impact of other factors (e.g., diurnal fluctuations and other factors) on recharge estimate; 6 ) aggregate the hourly positive water-table change time-series into a monthly time-series; 7) multiply the monthly water-table rise time-series by the specific yield to obtain the 
is different to the approach presented by Crosbie et al (2005) where a specific yield varying with depth was applied.

237 Selection of appropriate values of specific yield for use in the WTF method is very challenging, in particular for fractured hard rock aquifers. This is because aquifer tests for estimating specific yield are usually unreliable for determining the specific yield in fractured rock systems due to the limitations of the methods. These include the non-uniqueness of data interpretation as well as the difficulty in verifying the validity of assumptions inherent in the techniques (Bardenhagen, 2000; Freeze and Cherry, 1979). Specific yield obtained from other field methods for example the waterbudget method is considered to better represent the field conditions of fractured rock systems as this does not require any assumptions concerning the flow processes (Healy, 2010). The detailed discussions of selecting appropriate values for the recharge estimate and its limitations in this study are presented in the later section (section 6.3).

\section{Results and discussions}

\subsection{Groundwater-level fluctuations}

Figures 2 and 3 show groundwater-level and rainfall time-series data at the Glencastle and Gortinlieve sites over two hydrological years (October 2010 to September 2012). There are a total of 21 individual wells installed in clusters across both sites, monitoring groundwater level for specific depth intervals and along differing hillslope elevations (Table A.1). However, only 20 water-level timeseries data are available as the well installed within the subsoil at the high elevation close to the top of the hillslope at Glencastle (GC1-SS) was dry during this period. At Glencastle, water-level variations over the two hydrological years show a distinctive pattern in each well cluster. The water-level in the well cluster at the high elevation of the hillslope (GC1) shows a smooth and seasonal change between recharge and recession periods with an annual variation of $4-5 \mathrm{~m}$. Water levels in the intermediate elevation cluster (GC2) are remarkably stable throughout the year with an annual variation of less than $0.35 \mathrm{~m}$, while a 'flashy' hydrograph showing rapid responses to individual rainfall events was 
than $0.6 \mathrm{~m}$. The distinctive patterns of groundwater-level hydrographs in the three well-clusters at

262 Glencastle underlie different hydrogeological regimes influencing the groundwater flow and storage.

263 With GC1 installed in the mica schist and gneiss bedrocks without hydraulically active fractures

264 (CMD and OCM, 2010a), the smooth and seasonal change of groundwater hydrograph may indicate

265 that recharge in this bedrock unit is dominated by the slow flow pathways. These flow pathways are

266 likely controlled by the matrix flow which is similar to those reported in chalk aquifers (e.g., Ireson et

267 al., 2009). The upward head gradient at GC2 (Figure 2) suggests that the relatively high permeability

268 layer of the transition zone $\left(5 \times 10^{-2} \mathrm{~m} / \mathrm{d}\right.$, Table A.1) may act as a conductive layer to drain the deep

269 groundwater towards the down gradient of the hillslope. This could result in the stable groundwater

270 levels throughout the year. Similar groundwater-level variations in shallow bedrock and transition

271 zone at this location indicate the hydraulic connection between the two units. No measurable changes

272 in groundwater-level within GC2-DB suggest that the well installed in the low permeable competent

273 gneiss bedrock $\left(10^{-6} \mathrm{~m} / \mathrm{d}\right.$, Table A.1) is isolated from the overlying units. The 'flashy' hydrographs

274 with the groundwater-level variations reflecting rainfall events at the base of the hillslope (GC3)

suggest a good hydraulic connection among the different hydrological units. The upward head gradient and the lowest groundwater levels being maintained at a higher level than the nearby stream level throughout the year indicate that both deep and shallow groundwater contribute to river stormflow and baseflow.

279 Unlike the Glencastle site, groundwater hydrographs at Gortinlieve can be grouped into three distinctive groups according to their variation patterns (Figure 3): 1) 'flashy' response to rainfall across a number of recharge and recession events within a daily/weekly timeframe (GO1-TZ, GO2$\mathrm{TZ}$ and GO3); 2) smooth response to rainfall across recharge and recession events within a weekly/monthly timeframe with seasonal variations (GO1-SB, GO2-SB and GO2-DB); 3) no apparent response to the rainfall events but with the seasonal variations (GO1-DB). These different variation patterns reflect the different hydrogeolocal settings where the wells have been installed. For example, with GO1-TZ and GO2-TZ installed in the conductive transition zone $\left(7 \times 10^{-2} \mathrm{~m} / \mathrm{d}\right.$, Table

287 A.1) overlain by a shallow $0.8 \mathrm{~m}$ subsoil, this geological setting supports rapid recharge and recession 
responsive to the rainfall events. The relative high-conductive units at GO3 (subsoil: $10 \mathrm{~m} / \mathrm{d}$, transition zone and bedrock units $3 \times 10^{-3}-4 \times 10^{0} \mathrm{~m} / \mathrm{d}$, Table A.1) suggest a good hydraulic connection

290 between the units at the base of the hillslope. As consequence of this, rapid and simultaneous responses to rainfall events were found in all wells at the GO3 cluster. Similar to GC3, the upward groundwater gradient and the higher groundwater level than the nearby stream level at GO3 indicate that both deep and shallow groundwater contribute to stormflow and baseflow. At GO1, three different types of groundwater hydrographs suggest different hydrological processes controlling groundwater-level variations among the transition zone, shallow and deep bedrocks. In contrast, a similar variation pattern in the shallow and deep bedrocks at GO2 may suggest similar hydrological processes controlling groundwater level fluctuations in these two bedrock units. Despite GO1 and GO2 being installed in similar bedrock units with similar permeabilities (Table A.1), the different patterns of groundwater hydrographs in the shallow and deep bedrocks at these two well clusters suggest that other factors apart from the rock permeability (e.g., topography and others) may also influence on water-level responses to rainfall.

Overall, analyses of the groundwater hydrographs at the two study sites highlights that the processes controlling groundwater-level response to rainfall are different in the different geological settings. This implies that further analyses of the groundwater-level and rainfall time-series must be carried out to indentify the key recharge mechanisms in the different geological layers, before applying the quantitative methods for recharge estimates. The analysis also suggests that deep and shallow groundwater at the base of the hillslope contributes to stormflow and baseflow throughout the year. In based on the measured water levels is presented by Figure A.1.

\section{$310 \quad 6.2 \quad$ Applications of the time-series analysis}

\section{$311 \quad$ 6.2.1 Auto-correlation and data characteristics}

312 Auto-correlation analysis for the rainfall and groundwater-level time-series data can reveal the

313 structure of the data. This could help to identify if other hydrological processes have impacts on the 314 water-level variations. At Glencastle, the auto-correlation functions of the rainfall and groundwater- 
level variations at the GC2 \& 3 clusters decline quickly and reach a null value (Figure 4a). This is an indicator of an uncorrelated characteristic of the hourly rainfall and groundwater-level variations over

317 the two hydrological years. Unlike GC2 \& 3 clusters, groundwater-level variations at the GC1 cluster show a very different behaviour, with the slow decline over a long time lag and the auto-correlation function still above the critical value of 0.2 after 100 hours lag time This represents a strong linear inter-relationship and daily/weekly repetition behaviour of the variable. With the GC1 cluster being installed in shallow and deep bedrock units without hydraulically active fractures (CMD and OCM, 2010a; Comte et al., 2012), the inter-relationship behaviour may suggest that the groundwater-level variations are influenced by the rock matrix storage, where the slow flow pathways within the matrix requires a long time to fill and drain the pores.

Unlike the Glencastle site, the auto-correlation functions at the Gortinlieve site are rather complex.

This includes: 1) an uncorrelated characteristic for rainfall as well as for the groundwater hydrographs at GO1-TZ, GO2-TZ and GO3; 2) an inter-relationship behaviour for GO1-SB and GO2-SB; 3) a periodic noise observed for GO1-DB and GO2-DB (Figure 4b). The uncorrelated characteristic at GO1-TZ, GO2-TZ and GO3 indicates limited storage effect on the water-level variations at these monitoring wells. This is consistent with the hydraulic test and well log data of the geological units indicating that these wells were installed in relatively high permeability units (Table A.1). Similar to those at GC1 (Figure 4a), the inter-relationship behaviour observed for the shallow bedrock at GO1SB \& GO2-SB may suggest that groundwater-level variations are influenced by the rock matrix storage within these units. A 24-hour periodic noise observed for the deep bedrock wells at GO1-DB \& GO2-DB may indicate an effect of diurnal tidal forcing (earth and/or atmospheric tides; Schulze et al. 2000) on groundwater levels in these two deep bedrock wells.

\subsubsection{Cross-correlation and recharge implications}

338 Cross-correlation analysis was used to determine groundwater-level response time to rainfall, by using

339 the respective time-series data as the input and output signal. The mean response time represents the

340 lag time of the peak cross-correlation coefficient for the time-series data over the two hydrological years. The seasonal response time was determined by the sliding windows cross-correlation method 
342

343

344

345

346

347

348

349

350

351

352

353

354

355

356

357

358

359

360

361

362

363

364

365

366

367

which uses subsets of three-month data from the whole dataset. For the Gortinlieve site, the rainfall time-series obtained in the rain gauge close to the top of the hillslope was used in the cross-correlation analyses for GO1 \& 2, while the measurements from the rain gauge at the base of the hillslope was used for GO3.

At Glencastle, the cross-correlation functions show a good correlation (peak $\gamma_{P, \Delta h}: \sim 0.5$ ) between rainfall and water-level variations for GC2-SS \& -TZ and GC3 within a time delay of 1 hour, while a fair correlation (peak $\gamma_{P, \Delta h}: \sim 0.2 \gg$ significant level of 0.015) was found for GC1 and GC2-SB with a time lag of $-1,-2$ and 3 hours, respectively (Figure 5a \& Table 1). The negative response time in shallow and deep bedrocks at GC1 indicates that rainfall does not have a direct influence on the groundwater-level fluctuation. This is consistent with the effect of the slow flow matrix storage identified by the auto-correlation analysis (Figure 4a). The longer response time ( 3 hours) with a lower peak value of $\gamma_{P, \Delta h}$ at GC2-SB than those (1 hour) for GC2-SS \& TZ and GC3 may indicate that, unlike the latter ones with the fast flow pathways for groundwater infiltration, the groundwaterlevel fluctuation at GC2-SB has been influenced by vertical fast flow via hydraulic active fractures combined with slow flow via the rock matrix within shallow bedrock unit. It is important to recognise that, due to the scales of data plotting in Figure 2, water-level responses to rainfall look identical for GC2-SS, TZ and SB. However, the hourly head response to rainfall over the two hydrological years at GC2-SB is much smoother than those at GC2-SS and TZ (Figure S.1 in the supplement), which attributes to a longer response time with a lower peak value of $\gamma_{P, \Delta h}$ at GC2-SB.

At Gortinlieve, the cross-correlation analysis reveals a rapid response to rainfall within 1-2 hours for GO1-TZ, GO2-TZ and GO3, while a slow response up to 19 hours was found for GO1-SB and GO2SB. In addition, a negative response time of -60 hours with a low peak $\gamma_{P, \Delta h}$ value (0.05) for GO1-DB and a response time of 26 hours for GO2-DB were observed (Figure $5 \mathrm{~b} \&$ Table 1). The rapid response to rainfall at GO1-TZ, GO2-TZ and GO3 suggests that water-level fluctuations in these wells are influenced by fast flow pathways. The slow response to rainfall at GO1-SB and GO2-SB indicates that water-level fluctuations are influenced by slow flow matrix storage. For GO1-DB and 
368 GO2-DB, the slow flow matrix storage and diurnal tidal forcing effects may be regarded as the main

369 reason for the negative and long response time.

370 Further analysis by the sliding window cross-correlation method shows that the seasonal variations in

371 rainfall have very limited impacts on the response times at the Glencastle site (Figure 6 \& Table 1).

372 The results show high seasonal peak values of $\gamma_{P, \Delta h}(0.29-0.60)$ with the rather stable seasonal

373 response time observed at GC2-SS, GC2-TZ and GC3 regardless of varying rainfall intensity over the

374 two hydrological years (Figure 6c\&d). This reiterates that groundwater infiltrations within these

375 geological units are dominated by fast flow pathways. For GC1, the relative stable negative seasonal

376 response time except for some variations between the end of 2010 and the beginning of 2011 (Figure

377 6b) again confirm that rainfall does not have a direct influence on the groundwater-level fluctuation.

378 The variations of the seasonal response times during the 2010 winter period are probably due to the

379 unusual heavy snow as a result of the unusual cold winter. The slow snow melting process in the

380 lower temperature of the hilltop could change the rainfall input into the aquifer. The seasonal

381 variability up to one order magnitude with the longer response times in the dry seasons and the shorter

382 ones in wet seasons at GC2-SB suggests a seasonal variability in the rock matrix storage. As water-

383 level at GC2-SB is higher than those at the shallow wells of GC2-SS and TZ, it is likely that the

384 seasonal variability was induced by the seasonal change of rock matrix storage up-gradient.

385 For the Gortinlieve site, the stable seasonal response time observed at GO2-TZ and GO3 with few

386 occasional outliers confirms that fast groundwater infiltration pathways are dominating within these

387 geological units again. However, there are some fluctuations observed in GO1-TZ, with a general

388 trend of a longer response times in the dry seasons and shorter ones in the wet seasons. This suggests

389 that the variations of the unsaturated thickness may have influences on seasonal groundwater

390 infiltration (Figure 7 \& Table 1). As expected, with the storage effect on GO1-SB and GO2-SB as

391 well as tidal forcing effects observed in groundwater-level variations at GO1-DB and GO2-DB, a

392 larger seasonal variability of the response was found among these wells. 
Overall the auto-and cross-correlation analysis reveal that groundwater infiltration at GC2-SS, GC2-

TZ, GC3, GO1-TZ, GO2-TZ and GO3 is dominated by fast flow pathways, with a limited seasonal variability of the response time. In contrast, groundwater infiltration at GC1-SB, GC1-DB, GO1-SB and GO2-SB is likely dominated by slow flow matrix storage. The groundwater variations in GO1DB and GO2-DB contain a periodic noise which may reflect the effect of tidal forcing (earth/atmospheric). The seasonal change of matrix storage and tidal forcing effects may be regarded as the main reasons for seasonal variability of the response time observed in these wells.

\subsection{Groundwater recharge estimate}

401 As the WTF method is based on the assumption that rises in water-table in unconfined aquifers are due to direct recharge, we only use the groundwater hydrographs from 8 shallow wells (GC2-SS, GC2-TZ, GC3-SS, GC3-TZ, GO1-TZ, GO2-TZ, GO3-SS and GO3-TZ) to estimate groundwater recharge rates. In above correlation analyses, these wells showed water-level fluctuations dominated by fast groundwater infiltration pathways. Despite a similar infiltration behaviour being identified for GC3-SB, GC3-DB, GO3-SB and GO3-DB, these hydrographs have been not included in the recharge estimates, as it is uncertain whether these bedrock units may be regarded as unconfined aquifer given the observed upward head gradients.

Figure 8 shows the monthly accumulated water-table rise including the drainage term for the eight shallow wells at Glencastle and Gortinlieve over two hydrological years applying the WFT method

411 (Equation 6). Overall the monthly water-table rises correlate well with the monthly rainfall for each site, with a general trend of higher water-table rises occurring in wet winter months and lower ones in dry spring/summer months. For the Glencastle site, similar water-table rises were observed for the wells installed in the subsoil and transition zones of GC2 and GC3. This is an indication of these two geological units being well connected as the hydrographs between SS and TZ were overlapped in GC2 and GC3 (Figure 2) respectively. By using the same specific yield, the groundwater recharge

417 rates in the subsoil and transition zones at GC2 and GC3 are similar, despite the wells being installed into different geological units but having water-level fluctuating within the subsoil layer (Table 2). 
hillslope at GC3. To determine the causes for this difference is difficult, given that both GC2 and GC3

421

422

423

424

425

426

427

428

429

430

431

432

433

434

435

436

437

438

439 are overlain by a sandy - clay layer with a similar thickness (3-4 m, Table A.1). One possible explanation is the effect of the deep groundwater drainage towards the down gradient of the hillslope induced by the upward gradient at GC2.

For the Gortinlieve site, the monthly water-table rises for individual well are rather complex. In general, GO1-TZ is more responsive to rainfall than GO2-TZ, particularly in the wet season months. This is consistent with the groundwater hydrographs, as groundwater fluctuations at GO1-TZ are flashier than those at GO2-TZ (Figure 3). A similar pattern is also observed between GO3-SS and GO3-TZ. In particular, the result shows that the increases of rainfall in some periods of the second hydrological year (e.g., Oct-Dec 2011 and Jun-Jul 2012) has significant impact on the amount of water-table rise (Figure 8b). An increase of annual rainfall of $26 \%$ in the second year led to the increase of the annual water-table rise by $6.1 \mathrm{~m}$ for GO1-TZ, by $8 \mathrm{~m}$ for GO2-TZ, by $4.3 \mathrm{~m}$ for GO3SS and by $3.2 \mathrm{~m}$ for GO3-TZ when compared with those in the previous year (Table 2). The increase in rainfall has more impact on groundwater recharge at locations with a thinner subsoil layer $(0.8 \mathrm{~m}$ for GO1-TZ and GO2-TZ, $3.3 \mathrm{~m}$ for GO3-SS and $4.8 \mathrm{~m}$ for GO3-TZ, Table A.1). This is consistent with the previous study of the impact of subsoil thickness on recharge rates in Ireland (Misstear et al., 2009a). Statistical analysis of the rainfall intensity shows that, despite an increase of $\sim 250 \mathrm{~mm}$ rainfall in the low intensity events $(\leqslant 2 \mathrm{~mm} / \mathrm{h})$ for the second year, a similar distribution of the rainfall intensity was found for the two hydrological years (Figure 9). There are some substantial increases of the water-tables rises observed to GO1-TZ $(3.5 \mathrm{~m})$ and GO3-SS $(\sim 2 \mathrm{~m})$ in low rainfall density events $(\leqslant 1 \mathrm{~mm} / \mathrm{h})$ in the second year. However, their contributions to the annual water-table rises in percentage are similar to those in the previous year $(\sim 60 \%)$. In general, the low intensity rainfall events $(\leq 2 \mathrm{~mm} / \mathrm{h}$ ) contribute to $\sim 65-70 \%$ of the annual rainfall, and contribute $\sim 60-80 \%$ of the annual water-table rise (Figures 9c \& d). The increase of rainfall in the second year did not change the overall distributions of the rainfall intensity events contributing to the annual recharge, except a $10 \%$ of the annual recharge shifting towards the higher intensity rainfall events of $\geq 5 \mathrm{~mm} / \mathrm{h}$ being observed in GO3-TZ. The ratio of the water-table rise and rainfall show that the lower rainfall density group $(\leq 1$ 
$447 \mathrm{~mm} / \mathrm{h})$ has higher impact on the groundwater recharge rate. The higher intensity groups $(>1 \mathrm{~mm} / \mathrm{h})$

448 generally have a similar impact on groundwater recharge rate although some variations were found at 449 different wells.

450 Table 2 summarizes the annual recharge rates estimated by the WFT method, as well as the selected

451 specific yield values for recharge estimates. In this study, a specific yield of 0.01 and 0.005 was

452 chosen for the subsoil at both study sites and for the transition zone at Gortinlieve, respectively. These

453 values were obtained from studies of fractured rock site in east-central Pennsylvania (Gburek and

454 Folmar, 1999; Gburek and Urban, 1990; Heppner et al., 2007). The specific yield values were

455 obtained from the pan lysimeter measurements (e.g., water percolation rate) in the subsoil layers as

456 well as the combined analysis of the well hydrographs and the stream base-flow recession curve. The

457 similar values were also reported from another study of shale and limestone aquifers in Tennessee

458 using a similar method (Moore, 1992). We acknowledge that the selected specific yield of 0.01 for the

459 sandy-clay subsoil at Glencastle is slightly lower than those obtained from theoretical estimates (0.02-

460 0.07, Loheide et al., 2005) and field study in the South Eastern River Basin District in Ireland (glacial

461 till: 0.01-0.06, Tedd et al., 2012). In addition, the selection of appropriate values for specific yield for

462 the peaty clay subsoil layer in GC3 is very challenging, as few, if any, field observations of specific

463 yield of the peaty clay are available. Price and Schlotzhauer (1999) reported a specific yield of 0.048

464 for a mined peatland near Quebec, Canada. Loheide et al. (2005) also report the specific yield of 0.01-

4650.07 for the different types of clay. As groundwater levels in the subsoil fluctuate within $0.5-2 \mathrm{~m}$

466 below ground surface, a specific yield at the lower bound of reported values of 0.01 was selected to

467 estimate recharge rate in the subsoil to account for the likely capillary fringe effect. The selected

468 specific yield of 0.005 for the transition zone is an order of magnitude lower than the previous

469 reported value of storativity of 0.037 at Gortinlieve which was obtained from the pumping test

470 (Comte et al., 2012). Due to the drawbacks of pumping test to estimate specific yield in fractured rock

471 system (Bardenhagen, 2000; Freeze and Cherry, 1979), the estimated value was not used in this study.

472 Furthermore, the specific yield for the subsoil was used to estimate the recharge in transition zone of

473 GC2-TZ, GC3-TZ and GO3-TZ instead of using the specific yield for the transition zone. This is 
474 because the groundwater-level fluctuations in these three wells are within its overlying subsoil layer

475 despite the wells being installed in the transition zone.

476 With the WFT method, annual recharge rates were estimated to be $48-175 \mathrm{~mm} / \mathrm{yr}$ for the subsoil at

477 both sites (Table 2). These represent 5-19\% of the annual rainfall. For the transition zone, the slightly

478 lower recharge rates of $42-159 \mathrm{~mm} / \mathrm{yr}$ was obtained, which represent $4-17 \%$ of the annual rainfall.

479 The slightly lower recharge rates for the transition zone compared to the subsoil suggest that a small

480 percentage of the rainwater infiltration in the subsoil may travel down gradient via lateral flow within

481 the layer, which is consistent with general hillslope recharge mechanisms (e.g., Salve et al., 2012;

482 Uchida et al., 2003). The result also shows the spatial-temporal variations of the recharge rate for both

483 sites. In general, higher recharge rates are found at the base of the hillslope, while lower rates are

484 found at the hilltop and in the middle of the hillslope. Recharge rates at Gortinlieve are more sensitive

485 to the change of rainfall than those at Glencastle. An increase of the annual rainfall of $26 \%$ in the

486 second hydrological year led to the increase of the annual recharge rates of 40-90\% at Gortinlieve

487 (Table 2). Overall, the spatial variation of recharge rates found at both sites is consistent with

488 findings from other studies, as recharge rates estimated from the WTF method can be influenced by

489 differences in elevation, geology, land-surface slope, and other factors (e.g., Lee et al., 2005).

490 We recognise that the recharge rates estimated in this study using the WTF method contains

491 uncertainty which is difficult to quantify. The major challenge of this study is that there was no reported specific yield values obtained from the reliable field methods (e.g., the water budget method) for hard rock aquifers in Ireland. In addition, there were very limited field-scale studies which have been reported to estimate specific yield in the similar geological setting in other countries. Another challenge of the study is to quantify the recharge rates within shallow subsoil and transition zones where groundwater-level from $\sim 0.5 \mathrm{~m}$ to $2 \mathrm{~m}$ below ground surface. With such shallow depths of water levels, the impact of the capillary pressure on specific yield estimate is dependent on the heights of the capillary fringe in subsoil and transition zones. For the extreme cases where the depth to water table is less than the height of the capillary pressure, no water is released when water levels change (Childs, 1960; Healy, 2010). To quantify the uncertainty of the recharge estimates, field studies with 
501

502

503

504

505

506

507

508

509

510

511

512

513

514

515

516

517

518

519

520

521

522

523

524

525

526

527

sophisticated field instrumentations (e.g., Gburek and Folmar, 1999; Gburek and Urban, 1990;

Heppner et al., 2007) are required to estimate specific yield for different geological units which was beyond the scope of this study. In addition, it is important to recognise that the recharge rates estimated for the shallow layers of subsoil and transition zones in this study do not necessarily represent those in the deeper bedrock units. The low permeability of the deeper bedrock units can prevent further vertical infiltration of rainwater. This is evident from the correlation analyses which suggest that slow flow matrix storage controls water-level variations in shallow and deep bedrock wells at the top and in the middle of the hillslope. The low permeability of the bedrock could induce lateral water flow within the subsoil and transition zone, leaving only a small percentage of the infiltrated rainwater further migration into the deeper bedrock via hydraulically active fractures and slow flow pathways via the rock matrix.

\section{Conclusions}

In this study, we examined 19 groundwater level hydrographs from two Irish hillslope sites underlain by hard rock aquifer. The correlation analyses of rainfall and groundwater-level variations show the rapid groundwater-level response to rainfall ( $\leq 2$ hours) with little seasonal variability at all the wells completed in subsoil and transition zone as well as at wells installed in the shallow and deep bedrock units at the base of the hillslope. This suggests that groundwater recharge in the subsoil and transition zone as well as in the shallow and deep bedrock units at the base of the hillslope is dominated by fast infiltration flow pathways. For wells completed in the shallow and deep bedrock units close to the hilltop and at the middle of the hillslope, groundwater recharge in these shallow and deep bedrock units at these locations is dominated by slow flow matrix storage.

A modified WTF method has been also applied to estimate groundwater recharge rate using the groundwater-level and rainfall time-series in this study. In this approach, an automated time-series computer code was developed for the recharge estimate by accounting for the drainage effect. In addition, a procedure to examine the water-table rise by the antecedent rainfall was used to exclude the water-table rises with no rainfall in the recharge calculation. This procedure was to eliminate/limit the influences of diurnal fluctuations and other processes on recharge estimate. The results show 
528

529

530

531

532

533

534

535

536

537

538

539

540

541

542

543

544

545

546

547

annual recharge rates of $48-175 \mathrm{~mm} / \mathrm{yr}$ for the subsoil and $42-159 \mathrm{~mm} / \mathrm{yr}$ for the transition zone.

These represent $5-19 \%$ and $4-17 \%$ of the annual rainfall rate, respectively. Statistical analysis of the relationship between the rainfall intensity and water-table rise reveal that the low rainfall density group $(\leqslant 1 \mathrm{~mm} / \mathrm{h})$ has greater impact on the groundwater recharge rate than other rainfall groups $(>1$ $\mathrm{mm} / \mathrm{h}$ ). This study showed the usefulness of the correlation analyses to characterise the groundwater hydrograph and to understand the long-term and seasonal inter-relationship between groundwater level variations and rainfall. This provides critical information to reveal the underlying processes controlling water-level variations in the hard rock aquifers. Coupling the correlation analysis with the automated WFT method could provide a useful tool to estimate recharge rates in the hard rock aquifer.

\section{Acknowledgements}

Groundwater level data and ground levels of the clustered wells were provided by the Irish Environmental Protection Agency (Anthony Mannix and Patrick Durkin). We acknowledge Dr. Marie Archbold for providing rainfall data for the Gortinlieve site through the STRIVE Pathways project funded by the Irish Environmental Protection Agency. Rainfall data from Belmullet weather station was provided by the Irish Met Eireann. Rainfall data at the Ballykelly weather station was provided by the Met office through the BADC. This work is based on research grant-aimed by the Irish Department of Communications, Energy and Natural Resources under the National Geoscience Programme 2007-2013. We acknowledge the contribution of four anonymous reviewers in improving the final manuscript. 


\section{References}

549 Banks, E.W. et al., 2009. Fractured bedrock and saprolite hydrogeologic controls on groundwater/surface-water interaction: a conceptual model (Australia). Hydrogeology Journal, 17(8): 1969-1989. DOI:10.1007/s10040-009-0490-7

Bardenhagen, I., 2000. Groundwater reservoir characterisation based on pumping test curve diagnosis in fractured formation. In: Sililo, O. (Ed.), Groundwater: Past Acheivement and Future Challenges. Rotterdam: Balkema, pp. 81-86.

Cassidy, R. et al., 2014. Combining multi-scale geophysical techniques for robust hydro-structural characterisation in catchments underlain by hard rock in post-glacial regions. Journal of Hydrology, 517: 715-731. DOI:10.1016/j.jhydrol.2014.06.004

Caulfield, J., Chelliah, M., Comte, J.-C., Cassidy, R., Flynn, R., 2014. Integrating petrography, mineralogy and hydrochemistry to constrain the influence and distribution of groundwater contributions to baseflow in poorly productive aquifers: Insights from Gortinlieve catchment,

CDM and OCM, 2010a. Well Completion Report-Glencastle Catchment, Co. Mayo, Carlow County Council \& Environmental Protection Agency

CDM and OCM, 2010b. Well Completion Report-Gortinlieve Catchment, Co. Donegal, Carlow County Council and Environmental Protection Agency.

Chae, G.T., Yun, S.T., Kim, D.S., Kim, K.H., Joo, Y., 2010. Time-series analysis of three years of groundwater level data (Seoul, South Korea) to characterize urban groundwater recharge.

571 Childs, E.C., 1960. The Nonsteady state of the water table in drained land. Journal of Geophisical Research, 65: 780-782.

$$
\text { DOI:10.1144/1470-9236/07-056 }
$$

. Comte, J.-C. et al., 2012. The typology of Irish hard-rock aquifers based on an integrated hydrogeological and geophysical approach. Hydrogeology Journal, 20(8): 1569-1588. 
576 Crosbie, R.S., Binning, P., Kalma, J.D., 2005. A time series approach to inferring groundwater

577 recharge using the water table fluctuation method. Water Resources Research, 41(1).

$578 \quad$ DOI:W01008 10.1029/2004wr003077

579 Deakin, J., Archbold, M., Orr, A., O'Brien, R., Maher, P., Thompson, J., Cocchiglia, L., Misstear, B.,

580 Kelly-Quinn, M., Ofterdinger, U. and Flynn, R., 2015, Pathways Project Final Report Volume

581 1: Field Investigation and Catchment Conceptual Models EPA STRIVE Programme 2007-

582 2013 2007-WQ-CD-1-S1, Environmental Protection Agency, Wexford, Ireland

583 Delbart, C. et al., 2014. Temporal variability of karst aquifer response time established by the slidingwindows cross-correlation method. Journal of Hydrology, 511: 580-588.

586 DOI:10.1016/j.jhydrol.2014.02.008

Diggle, P.D., 1990. Time series: A Biostatistical Introduction. Oxford Statistical Science Series. Oxford Science Publication.

588

Fitzsimons, V.P., Misstear, B.D.R., 2006. Estimating groundwater recharge through tills: a sensitivity analysis of soil moisture budgets and till properties in Ireland. Hydrogeology Journal, 14(4): 548-561. DOI:10.1007/s10040-005-0450-9

Freeze, R.A., Cherry, J.A., 1979. Groundwater, Englewood Cliffs, NJ: Prentice-Hall Inc.

Gburek, W.J., Folmar, G.J., 1999. A ground water recharge field study: site characterization and initial results. Hydrological Processes, 13(17): 2813-2831. DOI:10.1002/(sici)10991085(19991215)13:17<2813::aid-hyp901>3.3.co;2-y

\section{Gburek, W.J., Urban, J.B., 1990. THE SHALLOW WEATHERED FRACTURE LAYER IN THE} NEAR-STREAM ZONE. Ground Water, 28(6): 875-883. DOI:10.1111/j.1745-

\subsection{0.tb01723.x}

GSI, 2006. A summary of the decision-making process and main criteria used in aquifer classification Healy, R.W., 2010. Estimating groundwater recharge. Cambridge University Press, Cambridge. Healy, R.W., Cook, P.G., 2002. Using groundwater levels to estimate recharge. Hydrogeology Journal, 10(1): 91-109. DOI:10.1007/s10040-001-0178-0 
602

603

604

605

606

607

608

609

610

611

612

613

614

615

616

617

618

619

620

621

622

623

624

625

626

627

628

629

Heppner, C.S., Nimmo, J.R., Folmar, G.J., Gburek, W.J., Risser, D.W., 2007. Multiple-methods investigation of recharge at a humid-region fractured rock site, Pennsylvania, USA. Hydrogeology Journal, 15(5): 915-927. DOI:10.1007/s10040-006-0149-6

Ireson, A.M., Mathias, S.A., Wheater, H.S., Butler, A.P., Finch, J., 2009. A model for flow in the chalk unsaturated zone incorporating progressive weathering. Journal of Hydrology, 365(3-4): 244-260. DOI:10.1016/j.jhydrol.2008.11.043

Jimenez-Martinez, J. et al., 2013. Temporal and spatial scaling of hydraulic response to recharge in fractured aquifers: Insights from a frequency domain analysis. Water Resources Research, 49(5): 3007-3023.

Jukic, D., Denic-Jukic, V., 2011. Partial spectral analysis of hydrological time series. Journal of Hydrology, 400(1-2): 223-233. DOI:10.1016/j.jhydrol.2011.01.044

Kosugi, K., Katsura, S., Katsuyama, M., Mizuyama, T., 2006. Water flow processes in weathered granitic bedrock and their effects on runoff generation in a small headwater catchment. Water Resources Research, 42(2). DOI:W02414 10.1029/2005wr004275

Larocque, M., Mangin, A., Razack, M., Banton, O., 1998. Contribution of correlation and spectral analyses to the regional study of a large karst aquifer (Charente, France). Journal of Hydrology, 205(3-4): 217-231. DOI:10.1016/s0022-1694(97)00155-8

Lee, J.Y., Lee, K.K., 2000. Use of hydrologic time series data for identification of recharge mechanism in a fractured bedrock aquifer system. Journal of Hydrology, 229(3-4): 190-201. DOI:10.1016/s0022-1694(00)00158-x

Lee, J.Y., Yi, M.J., Hwang, D., 2005. Dependency of hydrologic responses and recharge estimates on water-level monitoring locations within a small catchment. Geoscience Journal, 9(3):277-286.

Lee, L.J.E., Lawrence, D.S.L., Price, M., 2006. Analysis of water-level response to rainfall and implications for recharge pathways in the Chalk aquifer, SE England. Journal of Hydrology, 330(3-4): 604-620. DOI:10.1016/j.jhydrol.2006.04.025

Loheide, S.P., Butler, J.J., Gorelick, S.M., 2005. Estimation of groundwater consumption by phreatophytes using diurnal water table fluctuations: A saturated-unsaturated flow assessment. Water Resources Research, 41(7). DOI:W07030 10.1029/2005wr003942 
Mangin, A., 1984. THE USE OF AUTO-CORRELATION AND SPECTRAL ANALYSES TO OBTAIN A BETTER UNDERSTANDING OF HYDROLOGICAL SYSTEMS. Journal of Hydrology, 67(1-4): 25-43. DOI:10.1016/0022-1694(84)90230-0

McDonnell, J.J., 1990. A RATIONALE FOR OLD WATER DISCHARGE THROUGH MACROPORES IN A STEEP, HUMID CATCHMENT. Water Resources Research, 26(11): 2821-2832. DOI:10.1029/WR026i011p02821

McGlynn, B.L., McDonnel, J.J., Brammer, D.D., 2002. A review of the evolving perceptual model of hillslope flowpaths at the Maimai catchments, New Zealand. Journal of Hydrology, 257(1-4): 1-26. DOI:10.1016/s0022-1694(01)00559-5

McGrath, V., 2008. Determing the hydrologeological features of a poorly productive crystalline aquifer using manual field measurements, Queen's University Belfast, Belfast.

Misstear, B.D.R., Brown, L., Daly, D., 2009a. A methodology for making initial estimates of groundwater recharge from groundwater vulnerability mapping. Hydrogeology Journal, 17(2): 275-285. DOI:10.1007/s10040-008-0342-x

Misstear, B.D.R., Brown, L., Johnston, P.M., 2009b. Estimation of groundwater recharge in a major sand and gravel aquifer in Ireland using multiple approaches. Hydrogeology Journal, 17(3): 693-706. DOI:10.1007/s10040-008-0376-0

Misstear, B.D.R., Brown, L., Williams, N.H., 2008. Groundwater recharge to a fractured limestone aquifer overlain by glacial till in County Monaghan, Ireland. Quarterly Journal of Engineering Geology and Hydrogeology, 41: 465-476. DOI:10.1144/1470-9236/07-084

Misstear, B.D.R., Fitzsimons, V.P., 2007. Estimating recharge in fractured bedrock aquifers in Ireland. In: Krasny, J., Sharp, I.M. (Eds.), Groundwater in Fractured Rocks, IAH Selected Paper Series, pp. 243-257.

Moe, H., Craig, M., Daly, D., 2010. Poorly Productive Aquifers - Monitoring Installations and Conceptual Understanding, EPA.

Moore, G.K., 1992. HYDROGRAPH ANALYSIS IN A FRACTURED ROCK TERRANE. Ground Water, 30(3): 390-395. DOI:10.1111/j.1745-6584.1992.tb02007.x 
657

658

659

660

661

662

663

664

665

666

667

668

669

670

671

672

673

674

675

676

677

678

679

680

681

682

683

684

Nitsche, J., 2014. Physical characterisation of groundwater flow system of selected poorly productive bedrock aquifers in Ireland, PhD Thesis, Queen's University Belfast, Belfast.

O'Brien, R.J., Misstear, B.D., Gill, L.W., Johnston, P.M., Flynn, R., 2014. Quantifying flows along hydrological pathways by applying a new filtering algorithm in conjunction with master recession curve analysis. Hydrological Processes, 28(26): 6211-6221. DOI:10.1002/hyp.10105

Ofterdinger, U, Comte, J-C, Cassidy, R, Caulfield, J, Pilatova, K, Nitsche, J, Wilson, C, Cai, Z \& Flynn, R, 2015, Multidisciplinary investigations of poorly productive hard rock aquifers in Ireland: typologies, properties and significance in the Irish water cycle, Extended Abstract, IAH International Conference Hard Rock Aquifers: Up to date concepts and practical applications, La Roche-Sur-Yon, France, 11/06/2015 - 13/06/2015

Padilla, A., Pulidobosch, A., 1995. STUDY OF HYDROGRAPHS OF KARSTIC AQUIFERS BY MEANS OF CORRELATION AND CROSS-SPECTRAL ANALYSIS. Journal of Hydrology, 168(1-4): 73-89. DOI:10.1016/0022-1694(94)02648-u

PAUWELS, H., LACHASSAGNE, P., BORDENAVE, P., FOUCHER, J. C. \& MARTELAT, A. 2001. Temporal variability of nitrate concentration in a schist aquifer and transfer to surface waters. Applied Geochemistry, 16, 583-596.

PAWAR, N. J. \& SHAIKH, I. J. 1995. NITRATE POLLUTION OF GROUND WATERS FROM SHALLOW BASALTIC AQUIFERS, DECCAN TRAP HYDROLOGIC PROVINCE, INDIA. Environmental Geology, 25, 197-204.

Price, J.S., Schlotzhauer, S.M., 1999. Importance of shrinkage and compression in determining water storage changes in peat: the case of a mined peatland. Hydrological Processes, 13(16): 25912601. DOI:10.1002/(sici)1099-1085(199911)13:16<2591::aid-hyp933>3.0.co;2-e

Robins, N., Misstear, B.D.R., 2000. Groundwater in the Celtic regions. Geological Society London Special Publication, 182: 5-7.

Salve, R., Rempe, D.M., Dietrich, W.E., 2012. Rain, rock moisture dynamics, and the rapid response of perched groundwater in weathered, fractured argillite underlying a steep hillslope. Water Resources Research, 48. DOI:W11528 10.1029/2012wr012583 
685

686

687

688

689

690

691

692

693

694

695

696

697

698

699

700

701

702

703

704

705

706

707

Schulze, K.C., Kuempel, H.J., Huenges, E., 2000, In-situ petrohydraulic parameters from tidal and barometric analysis of fluid level variations in deep wells: some results from KTB, in I. Stober and K. Bucher (eds.), Hydrogeology of Crystalline Rocks, 79-104, Kluwer Academic Publishers, Netherlands

Shand, P., Darbyshire, D.P.F., Gooddy, D., Haria, A.H., 2007. Sr-87/Sr-86 as an indicator of flowpaths and weathering rates in the Plynlimon experimental catchments, Wales, UK. Chemical Geology, 236(3-4): 247-265. DOI:10.1016/j.chemgeo.2006.09.012

Swartz, M., Misstear, B.D.R., Daly, D., Farrell, E.R., 2003. Assessing subsoil permeability for groundwater vulnerability. Quarterly Journal of Engineering Geology and Hydrogeology, 36: 173-184. DOI:10.1144/1470-9236/2001-46

Tedd, K.M., Misstear, B.D.R., Coxon, C., Daly, D., Williams, N.H.H., 2012. Hydrogeological insights from groundwater level hydrographs in SE Ireland. Quarterly Journal of Engineering Geology and Hydrogeology, 45(1): 19-30. DOI:10.1144/1470-9236/10-026

Tromp-van Meerveld, H.J., Peters, N.E., McDonnell, J.J., 2007. Effect of bedrock permeability on subsurface stormflow and the water balance of a trenched hillslope at the Panola Mountain Research Watershed, Georgia, USA. Hydrological Processes, 21(6): 750-769.

DOI:10.1002/hyp.6265

Uchida, T., Asano, Y., Ohte, N., Mizuyama, T., 2003. Seepage area and rate of bedrock groundwater discharge at a granitic unchanneled hillslope. Water Resources Research, 39(1).

$$
\text { DOI:101810.1029/2002wr001298 }
$$

Williams, N.H.H., Misstear, B.D.R., Daly, D., Lee, M., 2013. Development of a national groundwater recharge map for the Republic of Ireland. Quarterly Journal of Engineering Geology and Hydrogeology, 46(4): 493-506. DOI:10.1144/qjegh2012-016 
Table 1 Summary of cross-correlation and three-month sliding cross-correlation of rainfall and groundwater-level variations.

\begin{tabular}{|c|c|c|c|c|c|c|c|c|}
\hline \multirow[b]{2}{*}{ Site } & \multirow[b]{2}{*}{ Cluster } & \multirow[b]{2}{*}{ Well } & \multicolumn{2}{|c|}{$\begin{array}{c}\text { Cross } \\
\text { correlation }^{a}\end{array}$} & \multicolumn{4}{|c|}{ Three-month sliding cross correlation } \\
\hline & & & $\begin{array}{l}\text { Peak } \\
\gamma_{P, \Delta h}\end{array}$ & $\begin{array}{l}\text { Lag- } \\
\text { time } \\
\text { (hrs) }\end{array}$ & $\begin{array}{c}\text { Shortest } \\
\text { lag-time } \\
\text { (hrs) }\end{array}$ & $\begin{array}{c}\text { Longest } \\
\text { lag-time } \\
\text { (hrs) }\end{array}$ & $\begin{array}{l}\operatorname{Max} \\
\gamma_{P, \Delta h}\end{array}$ & $\begin{array}{l}\text { Min } \\
\gamma_{P, \Delta h}\end{array}$ \\
\hline \multirow{10}{*}{ Glencastle } & \multirow[t]{2}{*}{ GC1 } & SB & 0.21 & -2 & -1 & 73 & 0.29 & 0.09 \\
\hline & & DB & 0.21 & -1 & 0 & 77 & 0.29 & 0.09 \\
\hline & \multirow{4}{*}{$\mathrm{GC} 2$} & SS & 0.51 & 1 & 1 & 2 & 0.54 & 0.35 \\
\hline & & $\mathrm{TZ}$ & 0.47 & 1 & 1 & 3 & 0.50 & 0.29 \\
\hline & & SB & 0.22 & 3 & 11 & 2 & 0.32 & 0.17 \\
\hline & & $\mathrm{DB}$ & NA & NA & NA & NA & NA & NA \\
\hline & \multirow{4}{*}{ GC3 } & SS & 0.50 & 1 & 0 & 1 & 0.58 & 0.33 \\
\hline & & $\mathrm{TZ}$ & 0.51 & 1 & 0 & 1 & 0.58 & 0.37 \\
\hline & & SB & 0.54 & 1 & 1 & 1 & 0.60 & 0.38 \\
\hline & & DB & 0.50 & 2 & 1 & 2 & 0.58 & 0.32 \\
\hline \multirow{10}{*}{ Gortinlieve } & \multirow{3}{*}{ GO1 } & $\mathrm{TZ}$ & 0.31 & 1 & 1 & 30 & 0.57 & 0.21 \\
\hline & & SB & 0.17 & 19 & 2 & 39 & 0.32 & 0.14 \\
\hline & & DB & 0.05 & -60 & 0 & -90 & 0.12 & 0.06 \\
\hline & \multirow{3}{*}{$\mathrm{GO} 2$} & $\mathrm{TZ}$ & 0.48 & 1 & 1 & 18 & 0.69 & 0.33 \\
\hline & & SB & 0.21 & 17 & 3 & 22 & 0.34 & 0.20 \\
\hline & & $\mathrm{DB}$ & 0.12 & 26 & 10 & 73 & 0.24 & 0.09 \\
\hline & \multirow{4}{*}{ GO3 } & SS & 0.46 & 1 & 1 & 3 & 0.68 & 0.43 \\
\hline & & $\mathrm{TZ}$ & 0.53 & 1 & 0 & 1 & 0.68 & 0.57 \\
\hline & & SB & 0.27 & 2 & 2 & 6 & 0.52 & 0.12 \\
\hline & & $\mathrm{DB}$ & 0.50 & 2 & 1 & 2 & 0.70 & 0.35 \\
\hline
\end{tabular}

${ }^{a}$ correlation using data from the two hydrological years. 
713 Table 2 Summary of groundwater recharge estimated by the WTF method

\begin{tabular}{|c|c|c|c|c|c|c|c|c|c|}
\hline \multirow[t]{2}{*}{ Year } & \multirow[t]{2}{*}{ Rainfall (mm/yr) } & \multicolumn{4}{|c|}{ Water-table rise $(\mathrm{m}) / \mathrm{S}_{\mathrm{y}}$} & \multicolumn{4}{|c|}{ GW recharge $(\mathrm{mm}) / \%$ of rainfall } \\
\hline & & GC2-SS & GC2-TZ & GC3-SS & GC3-TZ & GC2-SS & GC2-TZ & GC3-SS & GC3-TZ \\
\hline $10 / 11$ & 831 & $4.8 / 0.01^{\mathrm{a}}$ & $5.0 / 0.01^{b}$ & $14.7 / 0.01^{\mathrm{a}}$ & $13.7 / 0.01^{\mathrm{b}}$ & $48 / 6$ & $50 / 6$ & $147 / 18$ & $137 / 16$ \\
\hline $11 / 12$ & 924 & $4.8 / 0.01^{\mathrm{a}}$ & $5.1 / 0.01^{b}$ & $17.5 / 0.01^{\mathrm{a}}$ & $16.0 / 0.01^{b}$ & $48 / 5$ & $50 / 6$ & $175 / 19$ & $159 / 17$ \\
\hline & & GO1-TZ & GO2-TZ & GO3-SS & GO3-TZ & GO1-TZ & GO2-TZ & GO3-SS & GO3-TZ \\
\hline $10 / 11$ & 1134 & $13.6 / 0.005^{\mathrm{a}}$ & $8.8 / 0.005^{\mathrm{a}}$ & $7.4 / 0.01^{\mathrm{c}}$ & $4.2 / 0.01^{\mathrm{c}}$ & $68 / 6$ & $44 / 4$ & $74 / 7$ & $42 / 4$ \\
\hline $11 / 12$ & 1433 & $19.7 / 0.005^{\mathrm{a}}$ & $16.8 / 0.005^{\mathrm{a}}$ & $11.7 / 0.01^{\mathrm{c}}$ & $7.4 / 0.01^{\mathrm{c}}$ & $98 / 7$ & $84 / 6$ & $117 / 8$ & $74 / 5$ \\
\hline
\end{tabular}

$714{ }^{a}$ Specific yield for sandy-clay and transition zone (Gburek and Folmar, 1999); ${ }^{\text {b }}$ specific yield of sandy-clay used as the water-level fluctuation within the

715 subsoil layer; ${ }^{\mathrm{c}}$ Specific yield for peaty clay (Loheide et al., 2005; Price and Schlotzhauer, 1999). 

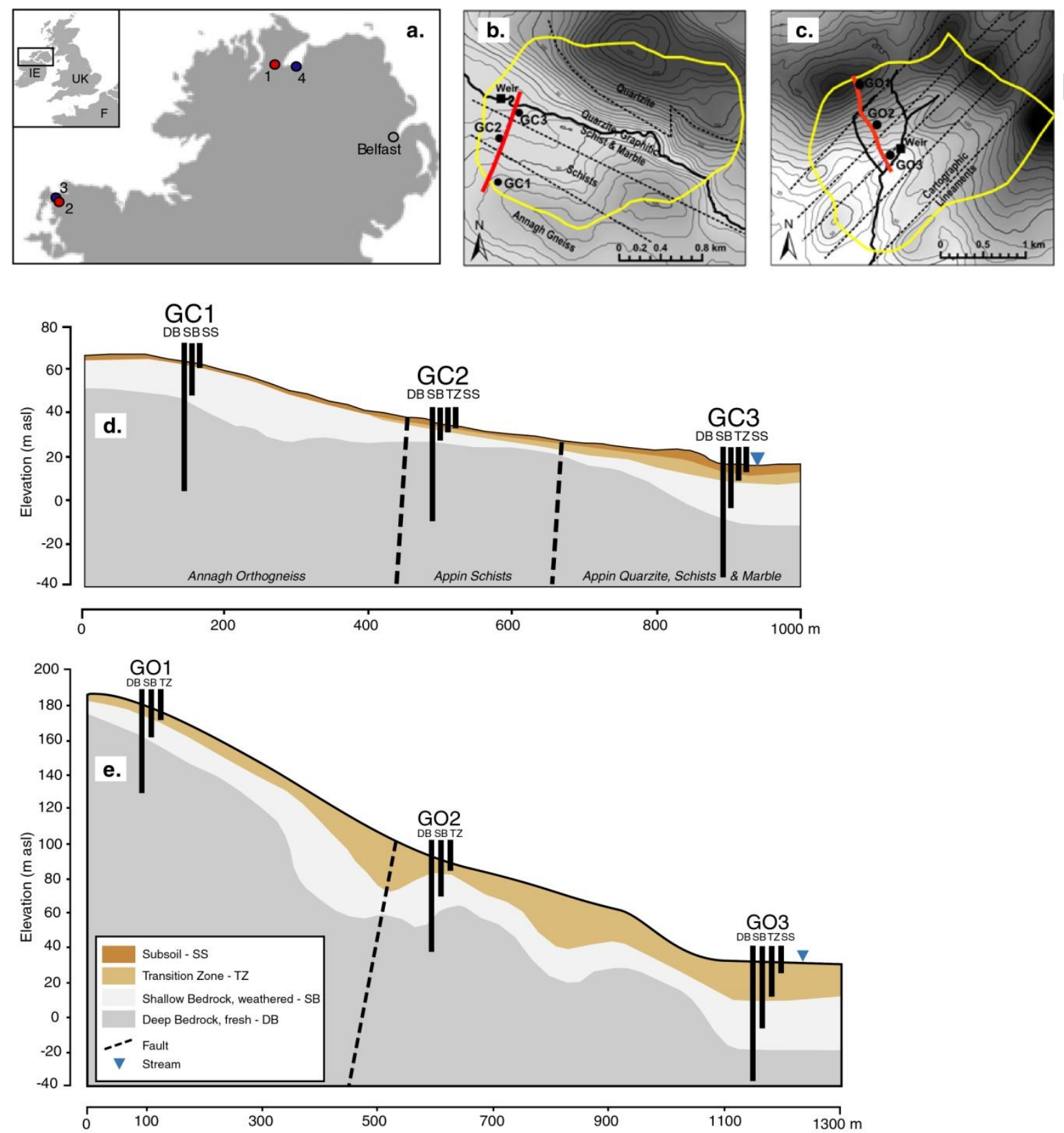

Figure 1: a) Location of study sites (1: Gortinlieve, 2: Glencastle) and meteorological stations (3:

720 Belmullet, 4: Ballykelly); Site layout maps of b) Glencastle site and c) Gortinlieve site indicating well

721 locations, structural lineaments, catchment boundaries (yellow) and profile sections (red); schematic cross-sections of d) Glencastle site and e) Gortinlieve site, indicating nested well installation and key geological zones as identified through electrical resistivity tomography and well log analysis (Comte et al. 2012). 


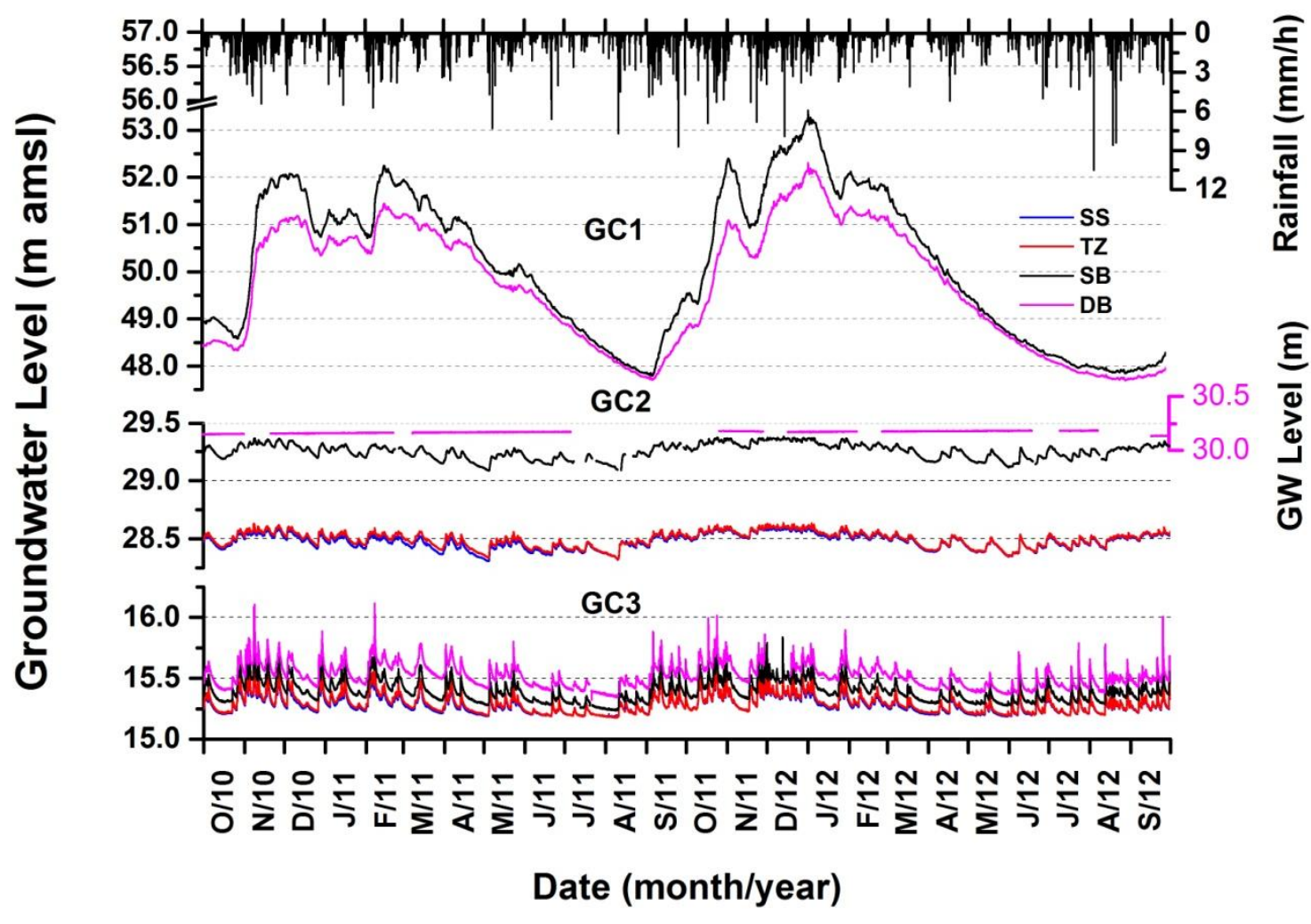

727 Figure 2. Rainfall and groundwater-level time-series in the Glencastle site. SS: Subsoil well; TZ:

728 Transition zone well; SB: Shallow bedrock well; DB: Deep bedrock well. 


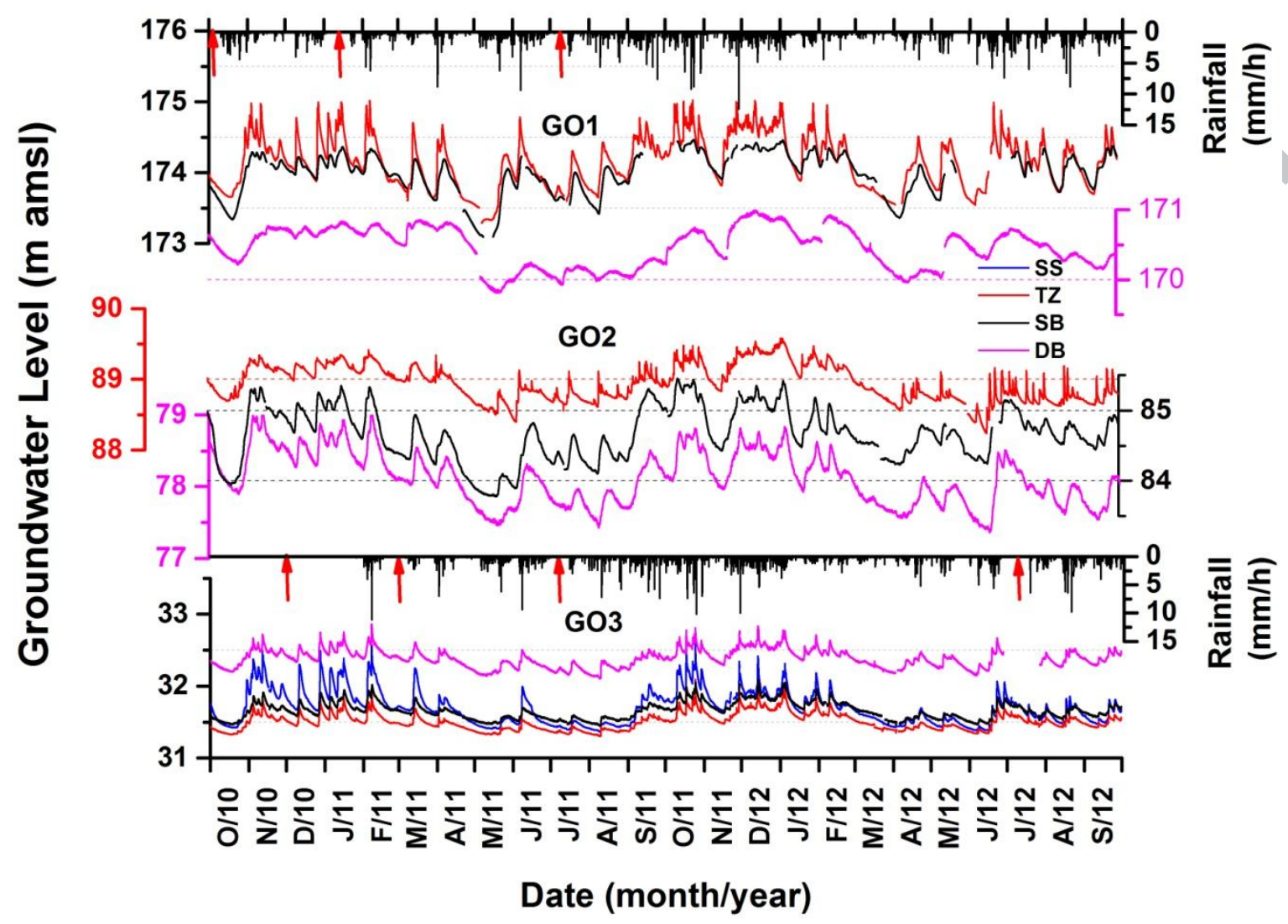

731

Figure 3. Rainfall and groundwater-level time-series in the Gortinlieve site. Note: red arrow pointing at the periods with no rainfall records from the upper and/or lower rain gauges. 
736

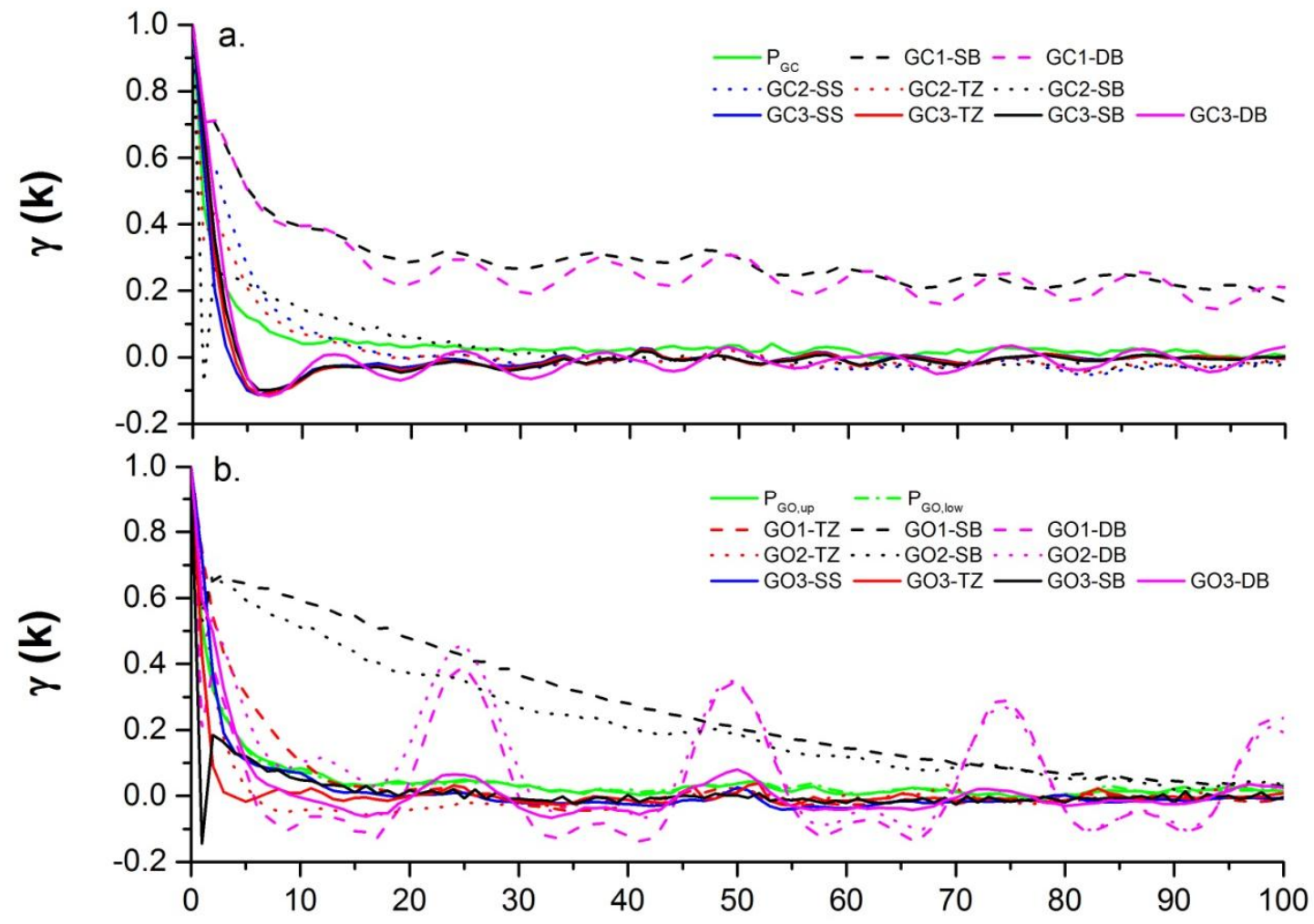

737

\section{Lag $k$ (hours)}

738 Figure 4 Autocorrelation of rainfall and groundwater-level hydrographs in the Glencastle (a) and

739 Gortinlieve (b) sites. 

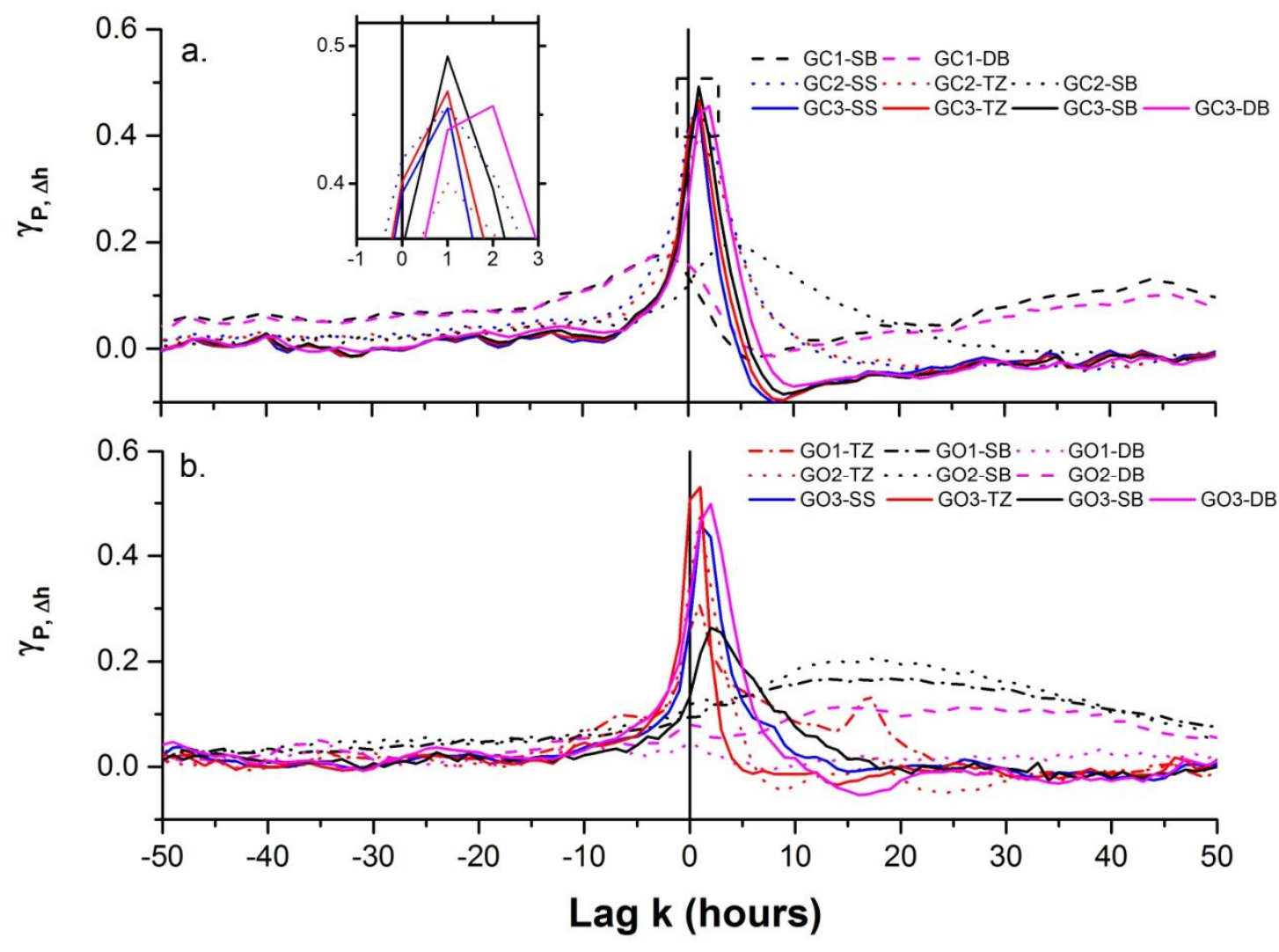

742

743 Figure 5. Cross-correlation between rainfall and groundwater-level hydrographs at Glencastle (a) and

744 Gortinlieve (b) sites. 


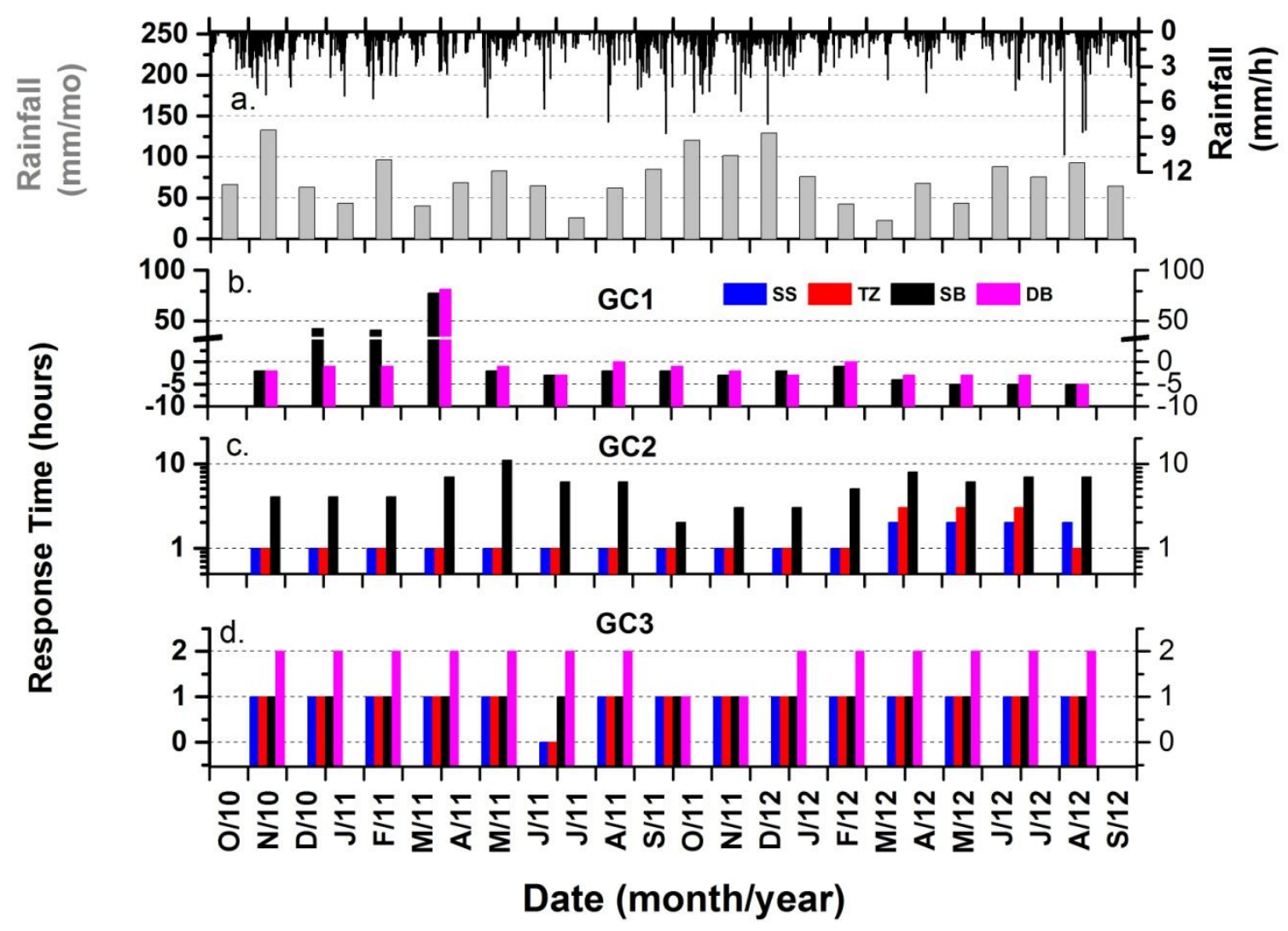

747 Figure 6. Rainfall (a) and the seasonal groundwater response time to rainfall in the Glencastle site (b-

748 d). Note: Rainfall during the period from December 2010 to March 2011 was represented by snowfall 749 due to the unusual cold winter. 


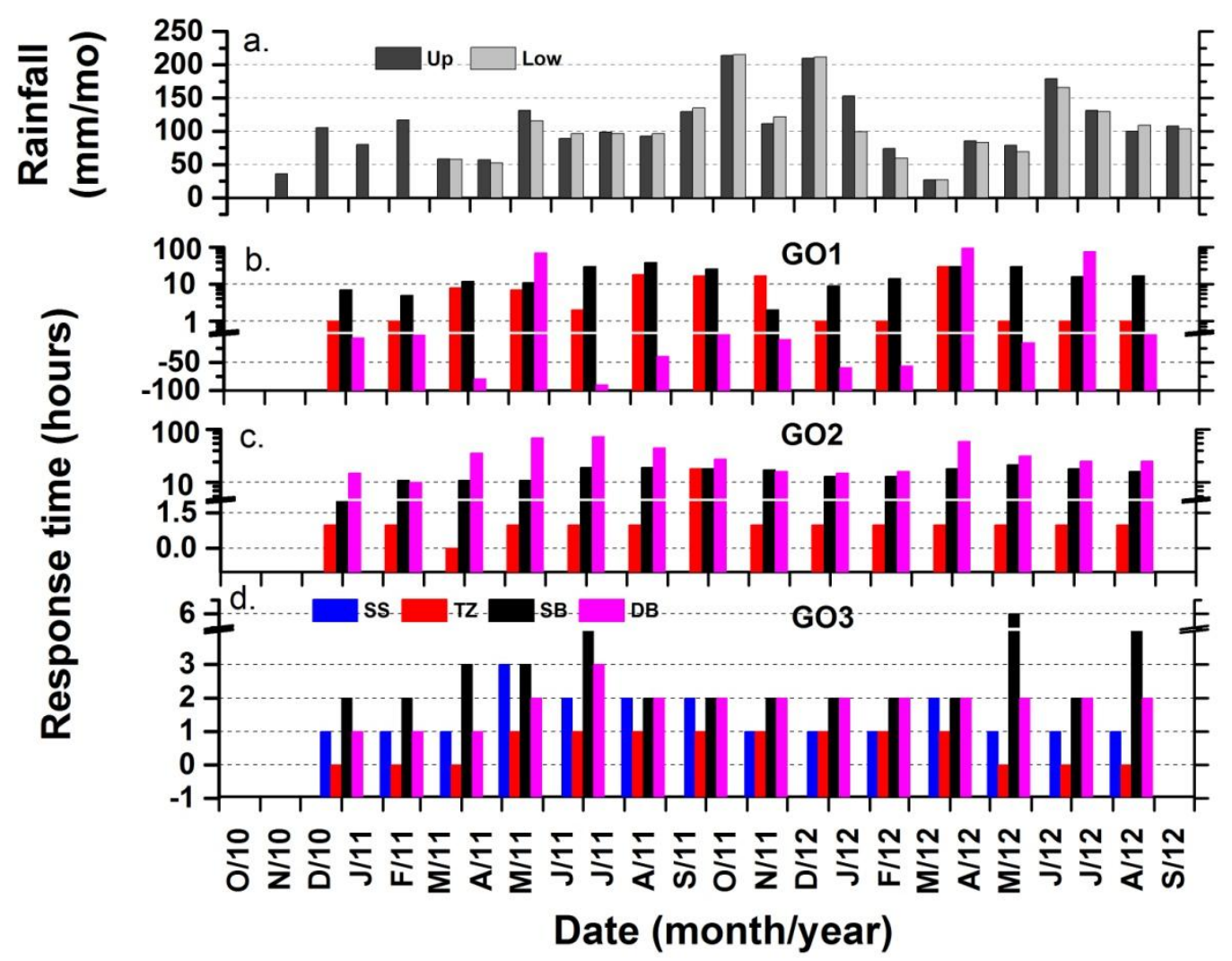

753 Figure 7. Rainfall (a) and the seasonal groundwater response time to rainfall in the Gortinlieve site (b-

754 d). Up: rainfall measurement in the hilltop; Low: rainfall measurement in the foothill. Note: 1) No

755 estimate of the seasonal response time in November 2010 as no rainfall measurements in the first 10

756 days in October 2010; 2) Rainfall during the period from December 2010 to March 2011 was

757 represented by snowfall due to the unusual cold winter. 

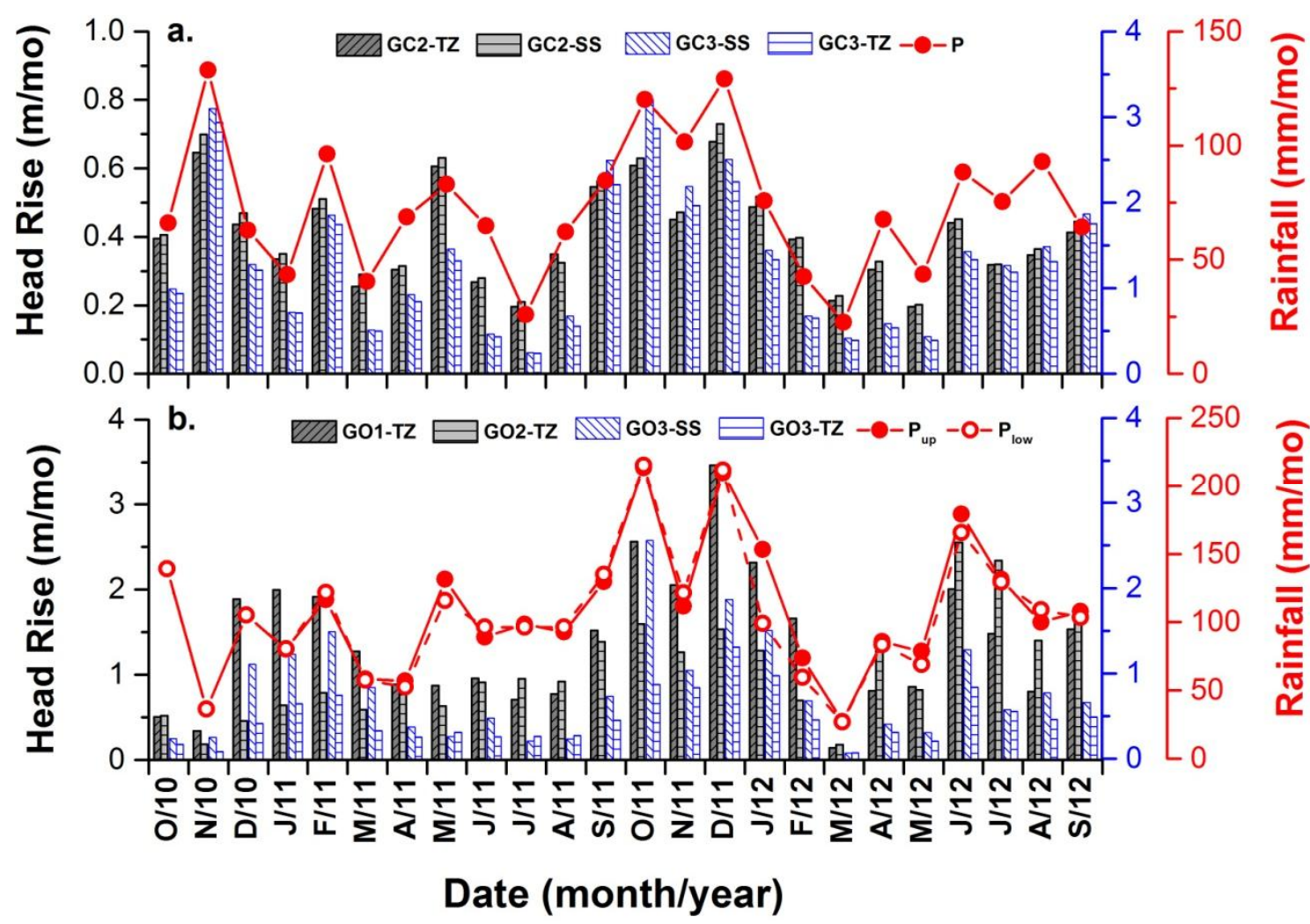

761

762 Figure 8. Monthly head rise estimated by the WFT method for the wells in the Glencastle (a) and

763 Gortinlieve sites (b) as well as monthly rainfall (P). 

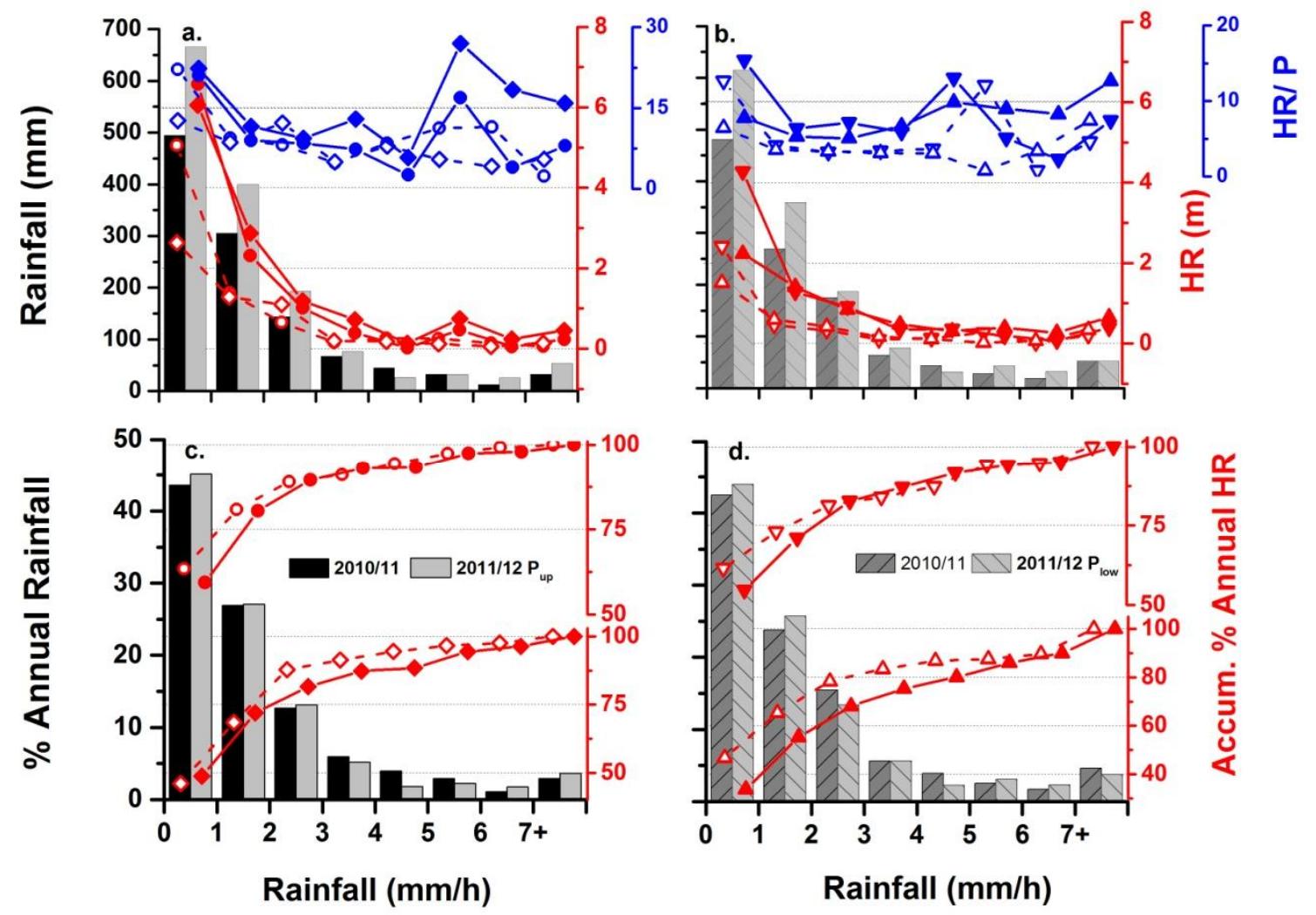

767

768 Figure 9. Impact of rainfall (P) intensity on measured head rise (HR) in the Gortinlieve site. a \& b: the

769 amount of rainfall and head rise, as well as their ratio (HR/P). c \& d: the annual proportion of the

770 rainfall and the accumulative head rise. Legend: circle, GO1-TZ; diamond, GO2-TZ; down-pointing

771 triangle, GO3-SS; up-pointing triangle, GO3-TZ; none fill colour symbol, 2010/11; fill colour symbol,

772 $2011 / 12$. 
775 Table A.1. Well characteristics from driller's logs and aquifer permeability from pumping tests at the Glencastle and Gortinlieve sites.

\begin{tabular}{|c|c|c|c|c|c|c|c|c|}
\hline & Cluster & Well & $\begin{array}{l}\text { Dept } \\
\mathrm{h} \\
(\mathrm{m})^{\mathrm{a}}\end{array}$ & Well type & $\begin{array}{l}\text { Well } \\
\text { Interval } \\
\left.(\mathrm{m} \mathrm{bgl})^{\mathrm{a}}\right)\end{array}$ & $\begin{array}{l}\text { Subsoil } \\
\text { thickness } \\
\text { (m) }\end{array}$ & Lithologies $\left(\mathrm{m} \mathrm{bgl}^{\mathrm{a}}\right)$ & $\begin{array}{l}\text { Permeability } \\
\left(\mathrm{K}_{\mathrm{h}}: \mathrm{m} / \mathrm{d}\right)\end{array}$ \\
\hline \multirow{11}{*}{ Glencastle $^{b}$} & \multirow{3}{*}{ GC1 } & SS & $2.1 \mathrm{~m}$ & 6" screen & $0.4-2.0$ & 2.1 & Poorly gravelly fine sand and trace till $(0-2.1)$ & NA \\
\hline & & SB & 22.9 & 6" open-hole & $7.0-22.9$ & 2.1 & Weathered Schist (2.4-20.1), & $5.6 \times 10^{-3}$ \\
\hline & & DB & 61.0 & 6" open-hole & $24.9-61.0$ & 2.4 & Gneiss: weathered (20.1-35.1), fresh (35.1-61). & $1.6 \times 10^{-3}$ \\
\hline & \multirow{4}{*}{ GC2 } & SS & 4 & 6" screen & $2.0-3.8$ & 4.0 & Poorly gravelly fine sand and trace till (0-4) & $6.7 \times 10^{-2}$ \\
\hline & & $\mathrm{TZ}$ & 7.1 & 6" screen & $4.9-6.9$ & 4.3 & Slightly weathered gneiss (3.7-4.3), & $5.1 \times 10^{-2}$ \\
\hline & & SB & 20.4 & 6" open-hole & $7.2-20.4$ & 3.7 & Gneiss: slightly weathered (4.3-8.5), fresh (8.5-20.4). & $6.1 \times 10^{-4}$ \\
\hline & & DB & 64.0 & 6" screen & $21.3-64.0$ & 4.3 & Fresh gneiss (21.3-64) & $1.1 \times 10^{-6}$ \\
\hline & \multirow{4}{*}{ GC3 } & SS & 3.1 & 6" screen & $0.9-2.9$ & 2.8 & Poorly gravelly fine sand, cobbles and trace till $(0-2.8)$ & $4.5 \times 10^{-2}$ \\
\hline & & $\mathrm{TZ}$ & 6.7 & 6" open-hole & 4.4-6.7 & 3.4 & highly \& moderately weathered quartzite (4.4-6.7), & $1.9 \times 10^{-2}$ \\
\hline & & SB & 16.2 & 6" open-hole & $10.4-16.2$ & 2.7 & $\begin{array}{l}\text { Igneous rock: highly to moderately weathered (10.4- } \\
16.2 \text { ) }\end{array}$ & $1.3 \times 10^{-1}$ \\
\hline & & DB & 78.9 & 6" open-hole & $21.6-78.9$ & 3.1 & Quartzite: moderately to slightly weathered & $3.7 \times 10^{-4}$ \\
\hline \multirow{10}{*}{ Gortinlieve $^{c}$} & \multirow[t]{3}{*}{ GO1 } & $\mathrm{TZ}$ & 2.5 & 6" screen & $0.6-2.2$ & 0.8 & $\begin{array}{l}\text { Peaty-clay }(0-0.8) \text {; Psammite: heavily weathered with } \\
\text { clay cover }(0.8-1.5) \text {, weathered }(1.5-2.4)\end{array}$ & $7.6 \times 10^{-2 \mathrm{~d}}$ \\
\hline & & SB & 13.1 & 6" open-hole & $4.7-13.1$ & 0 & Weathered Psammite (4.7-13.1), WS at 10 & $1.4 \times 10^{-3}$ \\
\hline & & $\mathrm{DB}$ & 76.2 & 6" open-hole & $46.8-76.2$ & 0 & Weathered/fresh Psammite (13.1-76.4), WS at $54 \& 70$. & $6.6 \times 10^{-3}$ \\
\hline & \multirow[t]{3}{*}{$\mathrm{GO} 2$} & $\mathrm{TZ}$ & 3.0 & 6" screen & $0.6-2.8$ & 0.8 & Peaty and gravelly clay $(0-0.8)$ & $7.2 \times 10^{-2}$ \\
\hline & & SB & 15.2 & 6" open-hole & $7.9-15.2$ & 1.2 & Weathered Psammite (7.9-15.2), WS at $9 \& 11$. & $2.0 \times 10^{-3}$ \\
\hline & & SD & 67.1 & 6" open-hole & $29.3-67.1$ & 0.4 & Fresh PsaPsammite, WS at 36 & $1.3 \times 10^{-2}$ \\
\hline & \multirow[t]{4}{*}{ GO3 } & SS & 3.3 & 6" open-hole & $1.6-3.2$ & 3.3 & Clay and peat (0-2.20), silt (2.2-3.4) & $10^{\mathrm{e}}$ \\
\hline & & $\mathrm{TZ}$ & 7.1 & 6" open-hole & $4.7-6.9$ & 4.8 & $\begin{array}{l}\text { Heavily weathered Psammite with clay cover (4.8-6.7), } \\
\text { WS at 5.2 }\end{array}$ & $4.8^{\mathrm{d}}$ \\
\hline & & SA & 23.4 & 6" open-hole & $12.2-23.8$ & 7.2 & Weathered/fresh Psammite (8-23.4m), WS at $16 \& 19$ & $3.1 \times 10^{-3}$ \\
\hline & & $\mathrm{DA}$ & 53.3 & 6" open-hole & $36.3-53.3$ & 6.4 & $\begin{array}{l}\text { weathered/fresh Psammite (7.2-53.3m), WS at } 24,30 \\
\& 44\end{array}$ & $7.3 \times 10^{-2}$ \\
\hline
\end{tabular}




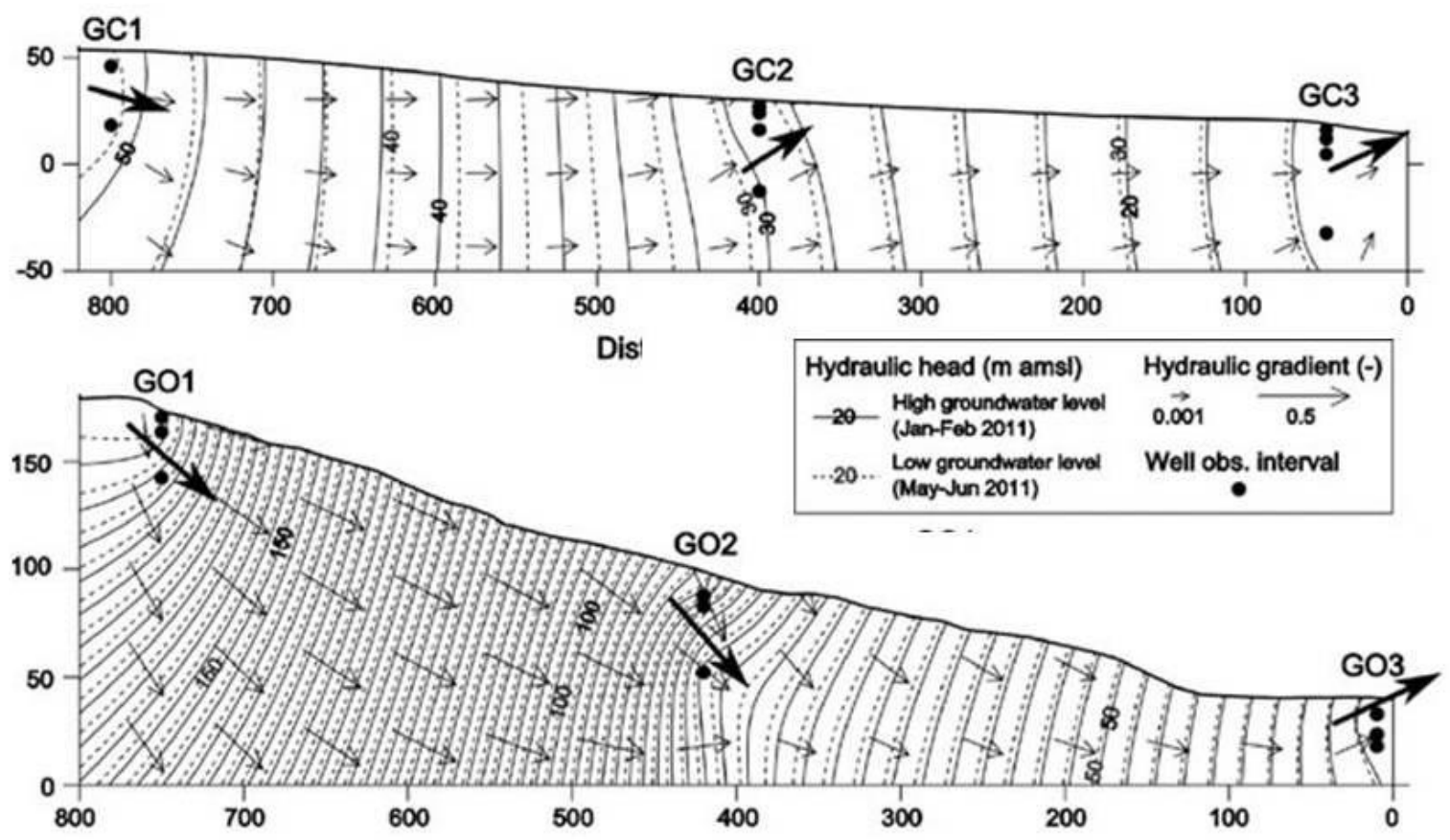

Figure A.1 Schematic representation of the groundwater flow processes along hillslopes towards the 779 river (dist. river $=0$ ). The bold black arrows show the mean winter hydraulic gradients near the wells 780 (after Comte et al., 2012). 

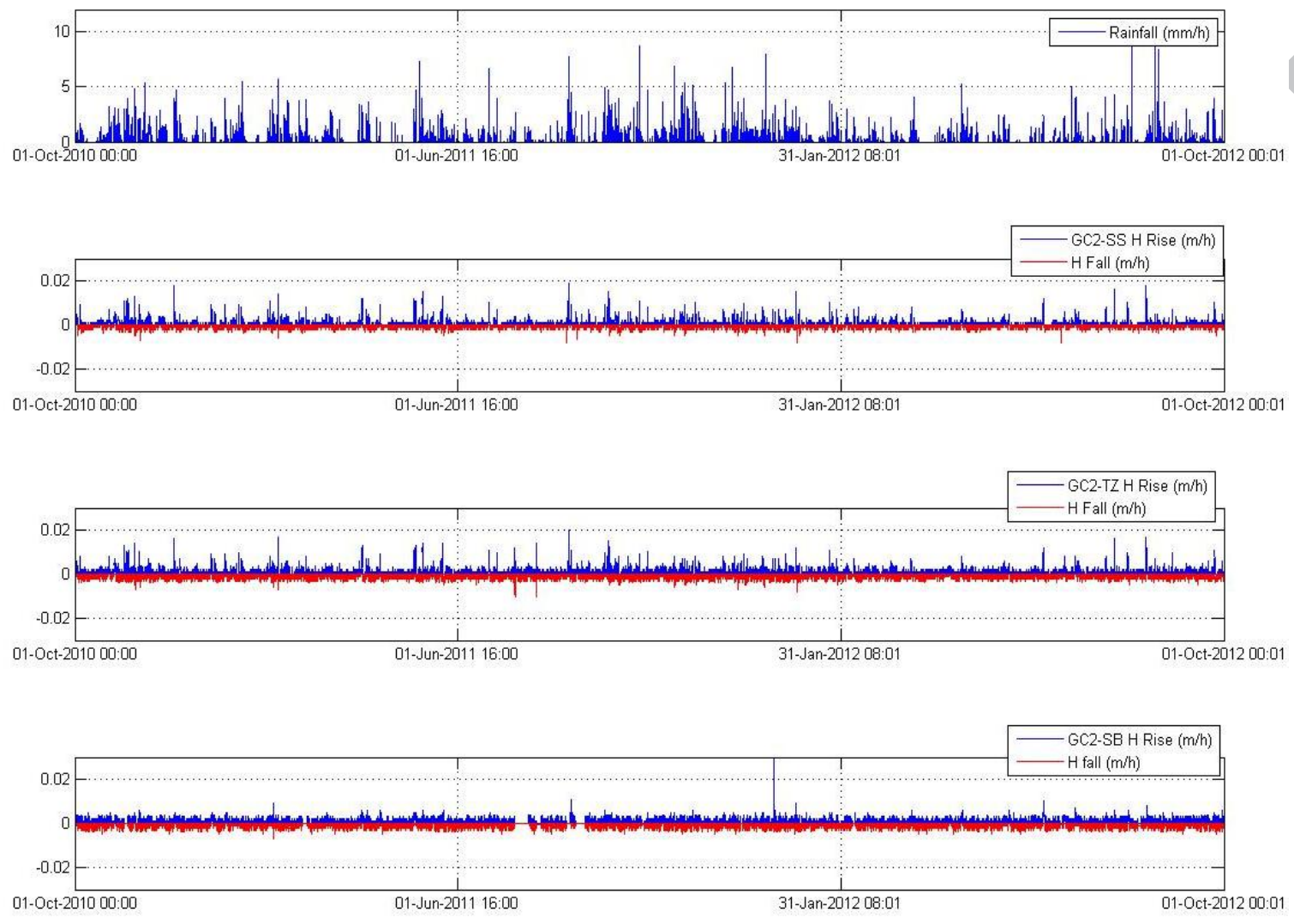

784 Figure S.1 Hourly rainfall and head changes at GC2-SS, TZand SB over the two hydrological years. 
Direct groundwater recharge to shallow or deep bedrocks on hillslope is very limited.

Direct recharge takes place within the subsoil and soil/bedrock interface.

Low intensity rainfall events $(\leq 1 \mathrm{~mm} / \mathrm{hr})$ have higher impact on recharge rate.

Recharge rates of 42-197 mm/yr were estimated. 